\title{
Effect of calcium intake on iron absorption and hematologic status: A systematic review and dose-response meta-analysis of randomized trials and case-cross-over studies
}

Ajibola Ibraheem Abioye ${ }^{1}$, Taofik A Okuneye ${ }^{2}$, Abdul-Majeed O Odesanya ${ }^{3}$, Olufunmilola Adisa ${ }^{4}$, Asanat I Abioye ${ }^{5}$, Ayorinde I Soipe ${ }^{6}$, Kamal A Ismail ${ }^{7}$, JaeWon F Yang ${ }^{8}$, Luther-King Fasehun ${ }^{9}$, Moshood O. Omotayo ${ }^{10,11}$

${ }^{I}$ Department of Nutrition, Harvard T.H. Chan School of Public Health, Boston MA, USA

${ }^{2}$ Department of Family Medicine, General Hospital, Odan, Lagos, Nigeria

${ }^{3}$ St Helen's \& Knowsley Teaching Hospitals NHS Trust, UK

${ }^{4}$ Emory University, Atlanta GA, USA

${ }^{5}$ University of Rhode Island, Kingston RI, USA

${ }^{6}$ Department of Emergency Medicine, Rhode Island Hospital, Providence RI, USA

${ }^{7}$ Department of Hematology, Lagos State University College of Medicine, Lagos, Nigeria

${ }^{8}$ Warren Alpert Medical School, Brown University, Providence RI, USA

${ }^{9}$ Wellbeing Foundation Africa, Abuja, Nigeria

${ }^{10}$ Centre for Global Health, Massachusetts General Hospital (MGH), Boston MA, USA

${ }^{11}$ Department of Pediatrics, Harvard Medical School, Boston MA, USA

Correspondence to: Moshood Omotayo, Centre for Global Health, Massachusetts General Hospital (MGH), Boston MA, USA.

Phone number: 617260972. Email: momotayo@mgh.harvard.edu

Number of words in manuscript, title through references $-5,531 \quad$ Number of Tables: 5

Running Title: Calcium intake and iron status

Abbreviations used in text:

AIC: Akaike Information Criteria; CI: Confidence Interval; CINAHL: Current Nursing and Allied Health Literature; LMIC: Low- and middle-income countries; MeSH: Medical Subject Headings; PRISMA: Preferred Reporting Items for Systematic Reviews and Meta-analysis; RCT: Randomized controlled trial; RR: Relative risk; SD: Standard deviation; se: Standard error; WHO: World Health Organization; WMD: Weighted mean differences

Authors' names for Pubmed indexing:

Abioye, Okuneye, Odesanya, Adisa, Abioye, Soipe, Ismail, Yang, Fasehun, Omotayo

Competing interests: All authors have completed the ICMJE uniform disclosure form at www.icmje.org/coi_disclosure.pdf and declare: no support from any organization for the submitted work; no financial relationships with any organizations that might have an interest in the submitted work in the previous three years; no other relationships or activities that could appear to have influenced the submitted work. 
medRxiv preprint doi: https://doi.org/10.1101/2020.09.21.20198358; this version posted September 23, 2020. The copyright holder for this preprint (which was not certified by peer review) is the author/funder, who has granted medRxiv a license to display the preprint in perpetuity. All rights reserved. No reuse allowed without permission.

\begin{abstract}
Background: The interaction between dietary (and supplementary) divalent ions has been a long-
\end{abstract} standing issue in human nutrition research. Developing optimal calcium and iron supplementation recommendation needs detailed knowledge of the potential trade-offs between: a) the clinical effects of concurrent intake on iron absorption and hematological indices, and b) the potentially negative effects of separated ingestion on adherence to either or both iron and calcium supplements. Human clinical studies have examined the effects of calcium intake on iron status, but there are no meta-analyses or recent reviews summarizing the findings. Objective: We aimed to summarize the literature on the effect of calcium consumption from meals and supplements on iron indices in humans, and quantify the pooled effects. Design: Peer-reviewed randomized and case-cross-over studies were included in this review. Result: The negative effect of calcium intake was statistically significant in short-term iron absorption studies but the effect magnitude was low (weighted mean difference (WMD) $=-5.57 \%$, (95\% CI: -7.09 , -4.04)). The effect of calcium on iron status was mixed. There was a quadratic dose-response relationship between calcium intake and serum ferritin concentration. Higher daily calcium intake was associated with a modest reduction in serum ferritin concentration. There was, however, no reduction in hemoglobin concentration $(\mathrm{WMD}=1.22 \mathrm{~g} / \mathrm{L}, 95 \% \mathrm{CI}: 0.37,2.07)$. Conclusion: The existing body of studies is insufficient to make recommendations with high confidence due to heterogeneity in design, limitations of ferritin as an iron biomarker and lack of intake studies in pregnant women. Prescribing separation of prenatal calcium and iron supplements in free living individuals is unlikely to affect the anemia burden. There is a need for effectiveness trials comparing the effects of prescribing separated intake to concurrent intake, with functional end-points as primary outcomes, and adherence to each supplement as intermediate outcomes.

Key words: Calcium and iron interaction, Calcium and preeclampsia, Maternal nutrition, Maternal Anemia, Meta-analysis 
medRxiv preprint doi: https://doi.org/10.1101/2020.09.21.20198358; this version posted September 23, 2020. The copyright holder for this preprint (which was not certified by peer review) is the author/funder, who has granted medRxiv a license to display the preprint in perpetuity.

\section{Introduction}

27 The interaction between dietary (and supplementary) divalent ions has been a long-standing issue in human nutrition research. Multiple studies have demonstrated that calcium inhibits iron absorption in short-term and single-meal studies (1-3). Studies that have measured the absorption ratio of iron in meals with different amounts of calcium have shown an inverse relationship(4). Two key mechanisms of action have been proposed for calcium-iron interaction(5). One potential mechanism is that luminal calcium leads to internalization of DMT1 receptors, limiting transfer of luminal iron into enterocytes. The other proposed mechanism is that calcium interferes with the transfer of iron across the enterocyte basolateral membrane. Recent reviews of inhibition mechanisms have provided some support for the first theory, but also suggested that homeostatic mechanisms compensate for the calcium-iron interaction, and the inhibitory effect is transient or at least not as clinically consequential as most shortterm absorption studies would suggest(4).

Developing optimal calcium and iron supplementation recommendation requires detailed knowledge of the potential trade-offs between: a) the clinical effects of concurrent intake on iron absorption and hematological indices, and b) the potentially negative effects of separated ingestion on adherence to

41 either or both iron and calcium supplements(6-8). While some studies have provided indication of the 42 direction of these relationships, results are conflicting. Data from dietary and supplementation studies 43 have been inconsistent, and it remains unclear whether there is a threshold dosage beyond which 44 calcium exerts its inhibitory effects, the value of such threshold, and factors that might affect the 45 threshold(9). Furthermore, longer-term studies that have examined the effect of calcium 
medRxiv preprint doi: https://doi.org/10.1101/2020.09.21.20198358; this version posted September 23, 2020. The copyright holder for this preprint (which was not certified by peer review) is the author/funder, who has granted medRxiv a license to display the preprint in perpetuity. All rights reserved. No reuse allowed without permission.

47 Prior narrative reviews have summarized existing studies of the interaction of dietary (and 48 supplementary) calcium and iron( $4,15-17)$. While the narrative reviews were comprehensive, they often

49

50

51

52

53

did not involve systematic and reproducible search strategy or meta-analysis. In addition, they did not include studies that have been published between 2010 and 2019, and we are unaware of any prior metaanalysis summarizing the clinical evidence on either of these issues. The objective of this study is to summarize human clinical studies that have examined the impact of calcium intake on iron status, identify factors moderating the effect and quantify the magnitude of the effect.

\section{Methods}

We followed the Preferred Reporting Items for Systematic Reviews and Meta-analysis (PRISMA) guidelines in the design, analysis, and reporting of this study (Supplement 1)(18). We identified studies examining the impact of calcium intake on iron outcomes, including iron absorption ratio and hematological indices. Original peer-reviewed research articles published up to August 2020 in the following medical literature databases were identified and examined for inclusion in the review: PUBMED/Medline (U.S. National Library of Medicine) and EMBASE (Elsevier). The databases were searched using queries composed of MeSH terms (Medical Subject Headings), EmTree terms and keywords representing iron, calcium and absorption/bioavailability. Hand searching of references was also done - specifically by examining the references of relevant systematic reviews and included studies as well as the first 500 hits on Google Scholar. No restrictions by age, year of publication or language were implemented. The title and abstract of each study were screened and full-texts examined in duplicate (Figure 1). A third author resolved discrepancies. Studies were excluded if they did not examine iron absorption or hematologic status, and did not examine calcium and iron intake, whether as supplements or in diet. If the diet differed by calcium intake and one or more other nutrient(s), the study was not included $(19,20)$. 
medRxiv preprint doi: https://doi.org/10.1101/2020.09.21.20198358; this version posted September 23, 2020. The copyright holder for this preprint (which was not certified by peer review) is the author/funder, who has granted medRxiv a license to display the preprint in perpetuity. All rights reserved. No reuse allowed without permission.

70 In terms of population, studies were not required to include only individuals who were healthy at

71 baseline or to exclude individuals who were anemic or pregnant. Only randomized controlled trials and

72 crossover studies were included, to facilitate causal interpretation of the effect of the interventions. The

73 studies had to have compared different doses of calcium intake in supplements or meals or compared

74 different sequences of calcium intake - keeping total daily intake constant.

75 Data extraction

76 Data extraction from full-text articles was done using a comprehensive extraction sheet. Information on

77 study design, population, intervention, covariates and findings were extracted. The median was extracted

78 if the mean was missing. Intake of calcium was converted to $\mathrm{mg} / \mathrm{day}$. Included studies provided calcium

79 in the test arm by altering the composition of meals, or providing calcium supplements. In some cases,

80 numerical values of total daily calcium intake were not provided, and were therefore imputed by

81 estimating the calcium content of meals provided using USDA reference(21). One study provided

82 estimates from the same individuals when iron absorption studies were conducted with and without

83 meals, and the estimates from studies without meal were included(2). If packed cell volume (PCV) was

84 provided, missing hemoglobin data was estimated by dividing PCV by 3. Only two studies provided iron

85 absorption estimates adjusted to ferritin $40 \mu \mathrm{g} / \mathrm{L}$, and the adjusted estimates were used $(22,23)$.

86

87

88

89

90

91

\section{Outcomes}

The primary outcomes of interest were the iron absorption ratio (\%) - total, heme and non-heme, serum ferritin $(\mu \mathrm{g} / \mathrm{L})$ and hemoglobin $(\mathrm{g} / \mathrm{L})$. While iron absorption ratio reflects short term effects, serum ferritin and hemoglobin reflect longer term effects. Regardless, all relevant outcomes reported in the included studies were reviewed. These include anemia (\%), mucosal uptake of iron (\% or mg), iron serosal transfer index, iron retention (mg), erythrocyte incorporation of iron (\% of absorbed iron), zinc 
medRxiv preprint doi: https://doi.org/10.1101/2020.09.21.20198358; this version posted September 23, 2020. The copyright holder for this preprint (which was not certified by peer review) is the author/funder, who has granted medRxiv a license to display the preprint in perpetuity.

92 protoporphyrin $(\mathrm{mmol} / \mathrm{L})$, soluble transferrin receptor $(\mu \mathrm{g} / \mathrm{L})$, mean corpuscular volume (fL) and iron

93

94

95

96

97

98

bioavailability (\% of absorbed iron).

\section{Risk of bias assessment}

We assessed the risk of bias of individual studies using the Cochrane risk of bias tool(24). For crossover trials, the Cochrane tool was modified as follows. Bias in randomization was described as high if the order of intervention was not randomized. In addition, bias due to carryover effects was assessed by the presence of absence of a washout period or a follow-up period non-interventional period ( $\geq 14 \mathrm{~d})$ in the studies. Two investigators independently assessed the studies and disagreements were resolved by consensus with a third author. This ranking did not influence decisions concerning exclusion of studies or analytic approach.

\section{Statistical analysis}

Included studies differed in the details of exposure assessment and outcome ascertainment. Random effects models, which explicitly model the between-study variation, were therefore selected a priori for the meta-analyses(25). Weighted mean differences for total, heme and non-heme iron absorption (\%) and serum ferritin $(\mu \mathrm{g} / \mathrm{L})$ were obtained from pooled analysis of the highest daily calcium intake compared to the lowest daily calcium intake. For studies reporting the outcome of interest at multiple time points, the longest reported follow-up was included in the main analysis.

Heterogeneity was formally assessed with the $\mathrm{I}^{2}$ statistics, a measure of the total variability that is due to between-study variation. $\mathrm{I}^{2}$ was regarded as low if $<50 \%$, substantial if $50-90 \%$ and considerable is $>90 \%$, in accordance with the general guidelines for Cochrane reviews, and p-values for Q-statistic reported(24). Heterogeneity was further assessed using meta-regression approaches and analysis within subgroups defined by age ( $<18,18-65$ and $\geq 65$ years), sex, nature of intervention (supplement or diet), and baseline iron status. The impact of an individual study on the WMD meta-analysis was evaluated by 
medRxiv preprint doi: https://doi.org/10.1101/2020.09.21.20198358; this version posted September 23, 2020. The copyright holder for this preprint (which was not certified by peer review) is the author/funder, who has granted medRxiv a license to display the preprint in perpetuity.

115 leaving one study out sequentially and obtaining pooled estimates. Publication bias was evaluated with 116 funnel plots and Egger's tests(26, 27).

117 Dose response meta-analysis of differences in means was conducted following the two-stage approach 118 proposed by Crippa and Orsini, based on restricted maximum likelihood estimation method(28, 29). 119 This approach makes no assumptions about the underlying shape of the association. Studies that did not 120 report more than 2 categories from the same sets of individuals were not included in the dose-response 121 meta-analysis $(11,23,30)$. Included studies measured outcomes on similar, interpretable scales, and 122 pooled difference estimates were therefore obtained on an absolute scale. Dose-response meta-analyses 123 were conducted using a variety of regression approaches - restricted cubic splines, fractional polynomial 124 and quadratic models, and the model with the lowest quantitative value of the Akaike Information 125 Criteria (AIC) was selected as the final model. In the presence of nonlinearity, the selected model was 126 presented in graphical form using predicted mean differences. Predicted mean differences for 1000, 1271500 and $2000 \mathrm{mg} / \mathrm{d}$ were obtained, in comparison to $500 \mathrm{mg} / \mathrm{d}$.

$128 P$-values are two sided and significance set at $p<0.05$. Statistical analyses were conducted using RStudio 129 1.0.153(16). Values presented in the text are means $( \pm \mathrm{SD})$, means $(95 \% \mathrm{CI})$, and means $( \pm \mathrm{SE})$.

\section{Results}

131 Description of studies

132 We identified 30 papers from an initial set of 1287 titles and abstracts (Figure 1) reporting on the 133 influence of consumption of calcium on iron absorption and hematologic indices. These were 12 134 randomized controlled trials $(1,10-12,14,22,31-36)$ and 18 case-crossover studies(2, 23, 30, 36-48), 135 including 1,623 and 592 participants respectively. The studies were conducted in Africa (14), Asia (10, $13631,36)$, Europe $(1,11,12,22,23,43)$, North America (2, 3, 13, 30, 34, 38, 39, 41, 44, 45, 47-49), and 137 South America (32, 33, 42). Fourteen of the studies included women only $(2,3,12-14,22,31,32,39$, 
medRxiv preprint doi: https://doi.org/10.1101/2020.09.21.20198358; this version posted September 23, 2020. The copyright holder for this preprint (which was not certified by peer review) is the author/funder, who has granted medRxiv a license to display the preprint in perpetuity. All rights reserved. No reuse allowed without permission.

$41,42,45,46,48,50,51)$. Almost all studies explicitly excluded pregnant or lactating women or both $(11,12,14,22,32,33,36,42,48)$ and none of the studies examined pregnant women alone. One study did not report the sex of participants (48). The interventions consisted of regular or low-calcium meals with or without calcium supplements $(1-3,11-14,23,30-33,36,39,41,42,46,48,51)$, or high-calcium versus low-calcium meals $(10,22,34,38,43-45,47,49,52)$. The studies assessed iron absorption using radiolabeled iron $(1,2,22,32,34,36,49)$ or gastrointestinal lavage and body scintillation procedures (30). Most of the studies were short-term and intervening over $<3$ months $(1,3,22,30-32,36,38,39$, $41,42,44-49,52)$, while others were longer-term and lasted $3-6$ months $(11,33)$ or $1-4$ years $(12,14$, 51). Of these, two studies evaluated the outcome at multiple time points, allowing their inclusion in both short term and long-term analyses $(11,14)$. Table 1 presents the characteristics of included studies.

Most of the included studies were of low risk of bias. The others were of moderate risk of bias $(1,10$, $11,14,22,30-33,36,42,48,51)$. Studies regarded as having a moderate risk of bias most often did not report (or perform) allocation concealment or blinding of participants and personnel.

\section{Total iron absorption}

We pooled 24 estimates from 7 studies $(1,2,11,22,23,30,34,36,39,42,43,46-49)$ to obtain weighted mean differences comparing the influence of high calcium intake on iron absorption relative to low calcium intake, and found that calcium intake was associated with lower iron absorption (Figure 2. $\mathrm{WMD}=-5.91,95 \% \mathrm{CI}:-8.38,-3.44 ; \mathrm{I}^{2}=84 \%, p$-heterogeneity<0.0001). Follow-up for the included studies was from $1-18$ days. There was no evidence from influence analysis that the pooled estimate was dominated by any of the individual studies. Neither the funnel plot nor Egger's mixed effects regression revealed any evidence of publication bias ( $p$-value $=0.75$; Supplementary Figure 1).

Heterogeneity was partly explained by the nature of the intervention $(\mathrm{p}<0.0001)$. The total iron absorption was -1.02 (95\% CI: $-3.77,1.73$ ) when intervention was based on meals alone, and differed by 
medRxiv preprint doi: https://doi.org/10.1101/2020.09.21.20198358; this version posted September 23, 2020. The copyright holder for this preprint (which was not certified by peer review) is the author/funder, who has granted medRxiv a license to display the preprint in perpetuity.

All rights reserved. No reuse allowed without permission.

-7.90 (95\% CI: -11.4, -4.3) when intervention was included supplements. Heterogeneity was not significantly explained by participant's age (p-heterogeneity $=0.78)$, sex (p-heterogeneity=0.19), baseline serum ferritin ( $\mathrm{p}$-heterogeneity=0.13), hemoglobin concentration ( $\mathrm{p}$-heterogeneity=0.64), duration of follow-up ( $\mathrm{p}$-heterogeneity $=0.19$ ) or year of publication ( $\mathrm{p}$-heterogeneity=0.43).

We pooled 32 difference measures from 3 absorption studies(1, 2, 36) using quadratic model-based meta-analysis to evaluate the dose-response relationship of calcium intake and the daily iron absorption

(Figure 3). The dose-response association of calcium intake on total iron absorption was significantly non-linear - total iron absorption was poorer with higher calcium intake $(p$-value $=0.026)$.

Heme iron absorption

We pooled 7 estimates from 4 studies $(1,23,42,48)$ to obtain weighted mean differences comparing the influence of high calcium intake on heme iron absorption relative to low calcium intake, and found that calcium intake was associated with a slightly lower heme iron absorption (Figure 4, WMD $=-4.84,95 \%$ CI: $-8.59,-1.09 ; \mathrm{I}^{2}=60 \%, p$-heterogeneity=0.021). Follow-up of the included studies was from $1-18$ days. All included studies had provided a supplement as the intervention. The influence of age, sex and baseline hematologic status on heterogeneity was not assessed due to missing covariate data. Visual inspection of the funnel plot suggests possible publication bias (Supplementary figure 2), although there was no evidence from Egger's test of small study effects ( $p$-value $=0.35)$.

We pooled 16 difference measures from 3 studies(1, 42, 48) using quadratic model-based meta-analysis to assess the presence of a non-linear dose response association. There was no evidence that the doseresponse association of calcium intake on heme iron absorption was non-linear ( $p$-value $=0.33$ ). Heterogeneity was, however, substantial $\left(\mathrm{I}^{2}=98 \%\right)$.

Non-heme iron absorption 
medRxiv preprint doi: https://doi.org/10.1101/2020.09.21.20198358; this version posted September 23, 2020. The copyright holder for this preprint (which was not certified by peer review) is the author/funder, who has granted medRxiv a license to display the preprint in perpetuity.

183 We pooled 11 estimates from 8 studies(2, 11, 22, 30, 34, 42, 43, 47, 48) to obtain weighted mean 184 differences comparing the influence of high calcium intake on non-heme iron absorption relative to low calcium intake, and found that calcium intake was associated with a slightly lower non-heme iron absorption (Figure 5. WMD $=-2.40,95 \%$ CI: $-4.98,0.18 ; \mathrm{I}^{2}=98 \%$, $p$-heterogeneity $<0.0001$ ), although the confidence limits included the null of 0 . Follow-up of the included studies was from $1-15$ days. Heterogeneity was not significantly explained by participant's age (p-heterogeneity $=0.90)$, sex $(p-$ heterogeneity=0.76), baseline serum ferritin ( $p$-heterogeneity=0.73), nature of intervention ( $p$ heterogeneity $=0.43$ ) or year of publication ( $\mathrm{p}$-heterogeneity=0.31). Visual inspection of the funnel plot suggested possible publication bias, though there was no evidence from Egger's test of small study effects (Supplementary Figure 4, p-value=0.29).

We pooled 44 difference measures from 5 studies $(22,34,42,47,48)$ using quadratic model-based metaanalysis. There was no evidence that the dose-response association of calcium intake on heme iron absorption was non-linear $(p$-value $=0.13)$. Heterogeneity was, however, substantial $\left(\mathrm{I}^{2}=96 \%\right)$.

We pooled 13 estimates from 13 studies $(10-14,30-34,50-52)$ to obtain weighted mean differences comparing the influence of high calcium intake and low calcium intake on serum ferritin concentration, and found no significant association of calcium intake and ferritin concentration (Figure 6. WMD = (95\% CI: -19.5, -3.53) compared to calcium from diet alone. Heterogeneity was not significantly explained by participant's age ( $\mathrm{p}$-heterogeneity=0.23), sex ( $\mathrm{p}$-heterogeneity $=0.11$ ), baseline serum 
medRxiv preprint doi: https://doi.org/10.1101/2020.09.21.20198358; this version posted September 23, 2020. The copyright holder for this preprint (which was not certified by peer review) is the author/funder, who has granted medRxiv a license to display the preprint in perpetuity. All rights reserved. No reuse allowed without permission.

heterogeneity $=0.61$ ) or year of study publication (p-heterogeneity=0.19). The duration of the interventions ranged from $2-52$ weeks. Heterogeneity was not significantly explained by duration of follow-up (p-heterogeneity=0.19). There was no evidence from influence analysis that the pooled estimate was dominated by any of the individual studies. There was also no evidence of publication bias from visual inspection of funnel plots (Supplementary Figure 5) as well as Egger's test for small study effects (p-value $=0.92)$.

We pooled 32 difference measures from 3 short-term studies $(12,31,47)$ using a quadratic model-based meta-analysis to explore dose-response relationship of calcium intake and iron absorption (Figure 7). The dose of calcium in the included studies ranged from $22-1,250 \mathrm{mg}$. The dose-response association of calcium intake with serum ferritin concentration was significant $(p$-value $=0.0004)$. Calcium intake was associated with reduced serum ferritin concentration as the dose increased. There was no meaningful heterogeneity $\left(\mathrm{I}^{2}=0 \%\right)$.

\section{Hemoglobin concentration}

We pooled 8 estimates from 6 studies $(10,12,32,33,50,51)$ to obtain weighted mean differences comparing the influence of high calcium intake on hemoglobin concentration relative to low calcium intake, and found that calcium intake no association with hemoglobin concentration (Figure 8. WMD = 0.44g/L, 95\% CI: -0.90, 1.78). There was substantial heterogeneity $\left(\mathrm{I}^{2}=77 \%, p\right.$-heterogeneity $\left.=0.001\right)$. The duration of intervention for the studies was $5-26 \mathrm{wks}$, with one study that lasted 4 years. When we excluded the long-term study in sensitivity analysis, the WMD was 1.22 (95\% CI: 0.37, 2.07).

Neither the funnel plot nor Egger's test for small study effects $(\mathrm{p}=0.17)$ suggested possible publication bias (Supplementary figure 6). There were too few studies reporting multiple dose categories $(n>2)$ and dose response analysis was not done. 
medRxiv preprint doi: https://doi.org/10.1101/2020.09.21.20198358; this version posted September 23, 2020. The copyright holder for this preprint (which was not certified by peer review) is the author/funder, who has granted medRxiv a license to display the preprint in perpetuity.

228 Sequencing of calcium intake

229 One study evaluated the extent to which the sequencing of calcium intake may influence iron 230 absorption(45). Keeping daily dietary calcium intake constant, the investigators compared the iron 231 absorption in 21 women who had dietary calcium at every meal to those who had no dietary calcium at 232 lunch and dinner. They found that total, non-heme and heme iron absorption were greater in those who 233 had no dietary calcium at lunch and dinner.

234 Other outcomes

235 Iron retention

236 Three studies $(3,38,41)$ examined the effect of calcium intake on iron retention. Among 11 boys and 237 girls in Texas, USA who participated in a case-crossover study(38), there was no significant difference 238 in the incorporation of iron into red blood cells between times when they were randomly assigned to 239 high calcium diets compared to low calcium diets (mean difference: $1.0 \%, 95 \%$ CI: $-6.2 \%$ to $4.2 \%$ ).

240 Two crossover studies in Boston, USA studied the effect of calcium intake on iron absorption among 241 postmenopausal women and found significantly lower retention of iron with intake of calcium from 242 different sources. Among 13 women(3), intake of either calcium carbonate (percent reduction: 43.3\% $243 \pm 8.8, \mathrm{p}=0.002$ ) or hydroxyapatite (percent reduction: $45.9 \% \pm 10, \mathrm{p}=0.003$ ) led to significantly lower 244 retention of iron, compared to placebo. Among 19 women(41), intake of milk (mean \pm SD: $3.4 \pm 3.4$ ) and 245 calcium citrate-malate salt (mean \pm SD: $6.0 \pm 4.2)$ led to significantly lower retention of iron $(\mathrm{p}<0.05)$, 246 compared to placebo (mean \pm SD: $8.3 \pm 4.6$ ).

\section{Discussion}

248 In this systematic review and meta-analysis, we summarized the human clinical studies that have 249 examined the impact of calcium intake on iron status. We found that calcium intake was associated with 250 overall reduced iron absorption and iron status in a dose dependent manner, but no impact on 251 hemoglobin concentration in the long term. The effect estimates were small and unlikely to be 
medRxiv preprint doi: https://doi.org/10.1101/2020.09.21.20198358; this version posted September 23, 2020. The copyright holder for this preprint (which was not certified by peer review) is the author/funder, who has granted medRxiv a license to display the preprint in perpetuity. All rights reserved. No reuse allowed without permission.

252 biologically significant. Overall, the inverse relationship between calcium intake and iron status is 253 unlikely to be clinically significant in free-living populations.

254 To the best of our knowledge, this is the first meta-analysis of the effect of calcium intake on iron status. 255 The issue of calcium-iron interaction has assumed renewed significance in recent years, particularly in 256 the context of low- and middle-income countries, due to recent WHO recommendations that calcium 257 supplementation be included in routine ante-natal care for prevention of preeclampsia. The WHO 258 currently recommends $1.5-2 \mathrm{~g}$ of calcium supplements for pregnant women in communities with 259 inadequate habitual calcium intake(53). The concern about the potential for a co-administered calcium 260 and iron supplementation regimen to worsen the burden of anemia in pregnancy is also one of the 261 justifications for calling for a lower dose for calcium supplementation $(8,54,55)$, besides the issues of 262 cost, logistical complexity and side effects.

263 Overall, our findings suggest that the magnitude of inhibition is unlikely to be clinically significant over 264 time even if separated intake is not prescribed, but these findings should be interpreted and applied in 265 the context of the weaknesses of the relevant body of work. We had set out to examine the impact of 266 combined intake on hematological indices that have been robustly linked to functional consequences 267 such as hemoglobin indices, over time periods that take iron homeostatic mechanisms into 268 consideration. Unfortunately, the only study that compared combined intake to separated intake was a 269 short-term study with iron absorption outcomes(45). There is a dearth of studies that have specifically 270 examined the effects of concurrent ingestion of iron and calcium supplements compared to delayed 271 intake of one or the other on biomarkers with well-established functional implications over extended 272 periods.

273 This study has other notable limitations. The evidence base is mostly informed by studies that have 274 examined the effect of different daily doses from meals and supplements on iron status over time, 
medRxiv preprint doi: https://doi.org/10.1101/2020.09.21.20198358; this version posted September 23, 2020. The copyright holder for this preprint (which was not certified by peer review) is the author/funder, who has granted medRxiv a license to display the preprint in perpetuity. All rights reserved. No reuse allowed without permission.

275 without indication of whether they were concurrently ingested or separated. In addition, the studies 276 reviewed included subjects from a broader population and not pregnant women in low and middle277 income countries only. In fact, most primary studies specifically excluded pregnant women; however the 278 key population motivating the renewed debate about calcium-iron interaction is pregnant women. 279 Moreover, the baseline iron status of the participants was not reported in many of the studies. It is well 280 known that extant iron status is an important determinant of iron metabolism. Given the location of most 281 of the studies in high income countries, it is plausible that the baseline iron status of participants might be higher than that of pregnant women in most communities in low- and middle-income countries. 283 Furthermore, we examined hematologic status using serum ferritin and hemoglobin concentration. Too 284 few studies have examined the effects of calcium intake on transferrin and other hematological markers 285 and indices with important physiological and functional implications(12). The significant limitations of 286 ferritin as a marker of iron status across populations is well known.

287 In conclusion, in the present systematic review and meta-analysis, we found statistically significant negative effect of calcium intake on iron status in the short term $(\leq 90$ days $)$, but the magnitude of the 289 effect was low and unlikely to be biologically significant, and longer-term studies consistently failed to 290 find this effect. In fact, despite the negative effect of calcium intake on iron absorption, hemoglobin 291 concentration was increased in this analysis. Our findings suggest that lowering the dose of calcium and 292 iron supplement intake among pregnant women is unlikely to affect the anemia burden in the long-term. 293 These findings should be interpreted with caution because of the significant heterogeneity and 294 limitations of the underlying studies. There is a need for effectiveness trials comparing the effects of 295 recommending separated supplement intake to combined intake among pregnant women in low and 296 middle-income countries, with blood pressure and iron status as primary outcomes, and adherence to 297 each supplement as intermediate outcomes. 
medRxiv preprint doi: https://doi.org/10.1101/2020.09.21.20198358; this version posted September 23, 2020. The copyright holder for this preprint (which was not certified by peer review) is the author/funder, who has granted medRxiv a license to display the preprint in perpetuity. All rights reserved. No reuse allowed without permission.

\section{Acknowledgment}

299 The authors are grateful to Dr Alessio Crippa of Karolinska Institutet for help with the R code for the 300 dose-response analysis.

301 AIA and MOO designed research; All authors extracted data from primary studies; AIA and MOO 302 analyzed data; AIA and MOO wrote the paper; MOO had primary responsibility for final content. All 303 authors read and approved the final manuscript. 
medRxiv preprint doi: https://doi.org/10.1101/2020.09.21.20198358; this version posted September 23, 2020. The copyright holder for this preprint (which was not certified by peer review) is the author/funder, who has granted medRxiv a license to display the preprint in perpetuity.

\section{Literature Cited}

1. Hallberg L, Rossander-Hulthen L, Brune M, Gleerup A. Inhibition of haem-iron absorption in man by calcium. The British journal of nutrition. 1993;69(2):533-40.

2. Cook JD, Dassenko SA, Whittaker P. Calcium supplementation: effect on iron absorption. The American journal of clinical nutrition. 1991;53(1):106-11.

3. Dawson-Hughes B, Seligson FH, Hughes VA. Effects of calcium carbonate and hydroxyapatite on zinc and iron retention in postmenopausal women. The American journal of clinical nutrition. 1986;44(1):83-8.

4. Lönnerdal B. Calcium and iron absorption-mechanisms and public health relevance. International Journal for Vitamin and Nutrition Research. 2010;80(4):293.

5. Shawki A, Mackenzie B. Interaction of calcium with the human divalent metal-ion transporter-1. Biochemical and biophysical research communications. 2010;393(3):471-5.

6. Omotayo M. Integrating Strategies For Prevention Of Pre-Eclampsia And Anemia In Pregnancy Into Primary Healthcare Delivery In Kenya. 2016.

7. Omotayo MO, Dickin KL, O'Brien KO, Neufeld LM, De Regil LM, Stoltzfus RJ. Calcium supplementation to prevent preeclampsia: translating guidelines into practice in low-income countries. Advances in Nutrition. 2016;7(2):275-8.

8. Omotayo MO, Dickin KL, Pelletier DL, Mwanga EO, Kung'u JK, Stoltzfus RJ. A simplified regimen compared with WHO guidelines decreases antenatal calcium supplement intake for prevention of preeclampsia in a cluster-randomized noninferiority trial in rural Kenya. The Journal of nutrition. 2017;147(10):1986-91.

9. Omotayo M, Dickin K, Stolzfus R. Perinatal mortality due to pre-eclampsia in Africa: a comprehensive and integrated approach is needed. Global Health: Science and Practice; 2016.

10. Agustina R, Bovee-Oudenhoven IMJ, Lukito W, Fahmida U, Van De Rest O, Zimmermann MB, et al. Lactobacillus reuteri DSM 17938 and lactobacillus casei CRL 431 modestly increase growth, not iron and zinc status, among indonesian children. Annals of Nutrition and Metabolism. 2013;63:212-3.

11. Minihane AM, Fairweather-Tait SJ. Effect of calcium supplementation on daily nonheme-iron absorption and long-term iron status. American Journal of Clinical Nutrition. 1998;68(1):96-102.

12. Mølgaard C, Kæstel P, Michaelsen KF. Long-term calcium supplementation does not affect the iron status of 12-14-y-old girls. American Journal of Clinical Nutrition. 2005;82(1):98-102.

13. Sokoll $\amalg$, Dawson-Hughes B. Calcium supplementation and plasma ferritin concentrations in premenopausal women. Am J Clin Nutr. 1992;56(6):1045-8.

14. Yan L, Prentice A, Dibba B, Jarjou LM, Stirling DM, Fairweather-Tait S. The effect of long-term calcium supplementation on indices of iron, zinc and magnesium status in lactating Gambian women. The British journal of nutrition. 1996;76(6):821-31.

15. Whiting SJ, Wood RJ. Adverse effects of high-calcium diets in humans. Nutrition reviews. 1997;55(1):1-9. 16. Whiting SJ. The inhibitory effect of dietary calcium on iron bioavailability: a cause for concern? Nutrition reviews. 1995;53(3):77-80.

17. Lynch SR. The effect of calcium on iron absorption. Nutrition research reviews. 2000;13(2):141-58.

18. Liberati A, Altman DG, Tetzlaff J, Mulrow C, Gøtzsche PC, loannidis JP, et al. The PRISMA statement for reporting systematic reviews and meta-analyses of studies that evaluate health care interventions: explanation and elaboration. PLoS medicine. 2009;6(7):e1000100.

19. Hennigar SR, Gaffney-Stomberg E, Lutz LJ, Cable SJ, Pasiakos SM, Young AJ, et al. Consumption of a calcium and vitamin D-fortified food product does not affect iron status during initial military training: a randomised, double-blind, placebo-controlled trial. British Journal of Nutrition. 2016;115(4):637-43. 
medRxiv preprint doi: https://doi.org/10.1101/2020.09.21.20198358; this version posted September 23, 2020. The copyright holder for this preprint (which was not certified by peer review) is the author/funder, who has granted medRxiv a license to display the preprint in perpetuity.

All rights reserved. No reuse allowed without permission.

20. Toxqui L, Pérez-Granados AM, Blanco-Rojo R, Wright I, González-Vizcayno C, Vaquero MP. Intake of an iron or iron and vitamin dfortified skimmed milk and iron metabolism in women. Annals of Nutrition and Metabolism. 2013;63:1609.

21. National Nutrient Database for Standard Reference [Internet]. National Agricultural Library. 2018 [cited 23 June 2019]. Available from: https://ndb.nal.usda.gov/ndb/.

22. Grinder-Pedersen L, Bukkave K, Jensen M, Højgaard L, Hansen M. Calcium from milk or calcium-fortified foods does not inhibit nonheme-iron absorption from a whole diet consumed over a 4-d period. American Journal of Clinical Nutrition. 2004;80(2):404-9.

23. Hallberg L, Brune M, Erlandsson M, Sandberg A-S, Rossander-Hulten L. Calcium: effect of different amounts on nonheme-and heme-iron absorption in humans. The American journal of clinical nutrition. 1991;53(1):112-9.

24. Higgins JP, Altman DG, Gøtzsche PC, Jüni P, Moher D, Oxman AD, et al. The Cochrane Collaboration's tool for assessing risk of bias in randomised trials. Bmj. 2011;343:d5928.

25. DerSimonian R, Laird N. Meta-analysis in clinical trials. Controlled clinical trials. 1986;7(3):177-88. 26. Duval S, Tweedie R. Trim and fill: a simple funnel-plot-based method of testing and adjusting for publication bias in meta-analysis. Biometrics. 2000;56(2):455-63.

27. Egger M, Smith GD, Schneider M, Minder C. Bias in meta-analysis detected by a simple, graphical test. Bmj. 1997;315(7109):629-34.

28. Crippa A, Orsini N. Dose-response meta-analysis of differences in means. BMC medical research methodology. 2016;16(1):91.

29. Crippa A, Crippa MA. Package 'dosresmeta'. 2017.

30. Roughead ZK, Zito CA, Hunt JR. Initial uptake and absorption of nonheme iron and absorption of heme iron in humans are unaffected by the addition of calcium as cheese to a meal with high iron bioavailability. Am J Clin Nutr. 2002;76(2):419-25.

31. Faghih S, Abadi AR, Hedayati M, Kimiagar M. The effect of the combination of restricted energy diet and low fat milk or calcium supplement on iron status of premenopausal overweight or obese women. Clinical Nutrition, Supplement. 2012;7(1):238-9.

32. Ríos-Castillo I, Olivares M, Brito A, López de Romaña D, Pizarro F. One-month of calcium supplementation does not affect iron bioavailability: A randomized controlled trial. Nutrition. 2014;30(1):44-8. 33. Miranda M, Olivares M, Brito A, Pizarro F. Reducing iron deficiency anemia in Bolivian school children: calcium and iron combined versus iron supplementation alone. Nutrition. 2014;30(7-8):771-5.

34. Reddy MB, Hurrell RF, Cook JD. Estimation of nonheme-iron bioavailability from meal composition. American Journal of Clinical Nutrition. 2000;71(4):937-43.

35. Sokoll L, Dawson-Hughes B. Calcium supplementation and plasma ferritin concentrations in premenopausal women. The American journal of clinical nutrition. 1992;56(6):1045-8.

36. Walczyk T, Muthayya S, Wegmuller R, Thankachan P, Sierksma A, Frenken LG, et al. Inhibition of iron absorption by calcium is modest in an iron-fortified, casein- and whey-based drink in Indian children and is easily compensated for by addition of ascorbic acid. The Journal of nutrition. 2014;144(11):1703-9.

37. Abrams SA, Griffin IJ, Davila P, Liang L. Calcium fortification of breakfast cereal enhances calcium absorption in children without affecting iron absorption. The Journal of pediatrics. 2001;139(4):522-6. 38. Ames SK, Gorham BM, Abrams SA. Effects of high compared with low calcium intake on calcium absorption and incorporation of iron by red blood cells in small children. The American journal of clinical nutrition. 1999;70(1):44-8.

39. Benkhedda K, L'Abbé MR, Cockell KA. Effect of calcium on iron absorption in women with marginal iron status. British journal of nutrition. 2010;103(5):742-8.

40. Dawson-Hughes B, Seligson F, Hughes V. Effects of calcium carbonate and hydroxyapatite on zinc and iron retention in postmenopausal women. The American journal of clinical nutrition. 1986;44(1):83-8. 
medRxiv preprint doi: https://doi.org/10.1101/2020.09.21.20198358; this version posted September 23, 2020. The copyright holder for this preprint (which was not certified by peer review) is the author/funder, who has granted medRxiv a license to display the preprint in perpetuity. All rights reserved. No reuse allowed without permission.

41. Deehr MS, Dallal GE, Smith KT, Taulbee JD, Dawson-Hughes B. Effects of different calcium sources on iron absorption in postmenopausal women. The American journal of clinical nutrition. 1990;51(1):95-9.

42. Gaitan D, Flores S, Saavedra P, Miranda C, Olivares M, Arredondo M, et al. Calcium does not inhibit the absorption of 5 milligrams of nonheme or heme iron at doses less than 800 milligrams in nonpregnant women. The Journal of nutrition. 2011;141(9):1652-6.

43. Galan P, Cherouvrier F, Preziosi P, Hercberg S. Effects of the increasing consumption of dairy products upon iron absorption. European journal of clinical nutrition. 1991;45(11):553-9.

44. Gleerup A, Rossander-Hulten L, Hallberg L. Duration of the inhibitory effect of calcium on non-haem iron absorption in man. European journal of clinical nutrition. 1993;47(12):875-9.

45. Gleerup A, Rossander-Hulthen L, Gramatkovski E, Hallberg L. Iron absorption from the whole diet: comparison of the effect of two different distributions of daily calcium intake. The American journal of clinical nutrition. 1995;61(1):97-104.

46. Monsen ER, Cook J. Food iron absorption in human subjects IV. The effects of calcium and phosphate salts on the absorption of nonheme iron. The American Journal of Clinical Nutrition. 1976;29(10):1142-8.

47. Reddy MB, Cook JD. Effect of calcium intake on nonheme-iron absorption from a complete diet. American Journal of Clinical Nutrition. 1997;65(6):1820-5.

48. Roughead ZK, Zito CA, Hunt JR. Inhibitory effects of dietary calcium on the initial uptake and subsequent retention of heme and nonheme iron in humans: comparisons using an intestinal lavage method. American Journal of Clinical Nutrition. 2005;82(3):589-97.

49. Abrams SA, Griffin IJ, Davila P, Liang L. Calcium fortification of breakfast cereal enhances calcium absorption in children without affecting iron absorption. Journal of Pediatrics. 2001;139(4):522-6.

50. Kalkwarf $\mathrm{H}$, Harrast SD. Effects of calcium supplementation and lactation on iron status. American Journal of Clinical Nutrition. 1998;67(6):1244-9.

51. Ilich-Ernst JZ, McKenna AA, Badenhop NE, Clairmont AC, Andon MB, Nahhas RW, et al. Iron status, menarche, and calcium supplementation in adolescent girls. The American journal of clinical nutrition. 1998;68(4):880-7.

52. Snedeker SM, Smith SA, Greger J. Effect of dietary calcium and phosphorus levels on the utilization of iron, copper, and zinc by adult males. The Journal of nutrition. 1982;112(1):136-43.

53. Organization WH. Guideline: Calcium supplementation in pregnant women: World Health Organization; 2013.

54. Hofmeyr G, Belizán J, Von Dadelszen P, Calcium, Group PeS. Low-dose calcium supplementation for preventing pre-eclampsia: a systematic review and commentary. BJOG: An International Journal of Obstetrics \& Gynaecology. 2014;121(8):951-7.

55. Omotayo MO, Dickin KL, Pelletier DL, Martin SL, Kung'u JK, Stoltzfus RJ. Feasibility of integrating calcium and iron-folate supplementation to prevent preeclampsia and anemia in pregnancy in primary healthcare facilities in Kenya. Maternal \& child nutrition. 2018;14:e12437. 


\section{$440 \quad$ Figures and Tables}

Figure 1. Flowchart of included studies

Figure 2. Forest plot for the relationship of calcium intake and total iron absorption (highest vs least calcium intake)

Figure 3. Dose-response relationship of calcium intake and total iron absorption

Figure 4. Forest plot for the relationship of calcium intake and heme iron absorption (highest vs least calcium intake)

Figure 5. Forest plot for the relationship of calcium intake and non-heme iron absorption (highest vs least calcium intake)

Figure 6. Forest plot for the relationship of calcium intake and serum ferritin (highest vs least calcium intake)

Figure 7. Dose-response relationship of calcium intake and serum ferritin concentration

Figure 8. Forest plot for the relationship of calcium intake and hemoglobin concentration

\section{Supplementary figures}

Supplementary figure 1 - Funnel plot for the relationship of calcium intake and total iron absorption (highest vs least calcium intake)

Supplementary figure 2 - Funnel plot for the relationship of calcium intake and heme iron absorption (highest vs least calcium intake)

Supplementary figure 3 - Funnel plot for the relationship of calcium intake and non-heme iron absorption (highest vs least calcium intake)

Supplementary figure 4 - Funnel plot for the relationship of calcium intake and serum ferritin (highest vs least calcium intake)

Supplementary figure 5 - Funnel plot for the relationship of calcium intake and hemoglobin concentration 
medRxiv preprint doi: https://doi.org/10.1101/2020.09.21.20198358; this version posted September 23, 2020. The copyright holder for this preprint (which was not certified by peer review) is the author/funder, who has granted medRxiv a license to display the preprint in perpetuity. All rights reserved. No reuse allowed without permission. 
441 Table 1. Characteristics of Included Studies

\begin{tabular}{|c|c|c|c|c|c|c|c|c|c|}
\hline $\begin{array}{l}\text { Author } \\
\text { (year) }\end{array}$ & $\begin{array}{c}\text { City, } \\
\text { Country }\end{array}$ & $\begin{array}{l}\text { Design; } \\
\text { Sample } \\
\text { size }(\mathbf{N})\end{array}$ & $\begin{array}{c}\text { Age; } \\
\text { \%Female }\end{array}$ & $\begin{array}{c}\text { Baseline } \\
\text { hematologic } \\
\text { status }\end{array}$ & $\begin{array}{c}\text { Duration of } \\
\text { intervention }\end{array}$ & Outcomes & $\begin{array}{c}\text { Description of } \\
\text { intervention (categories) }\end{array}$ & Findings $^{2}$ & $\begin{array}{c}\text { Risk of } \\
\text { bias }\end{array}$ \\
\hline $\begin{array}{l}\text { Abrams } \\
(2001)\end{array}$ & $\begin{array}{l}\text { Houston, } \\
\text { USA }\end{array}$ & $\begin{array}{l}\text { Case } \\
\text { crossover } \\
(\mathrm{N}=27)\end{array}$ & $\begin{array}{l}7.8 \mathrm{y} \\
48 \%\end{array}$ & NR & $\begin{array}{l}\text { Intervention: } 14 \mathrm{~d} \\
\text { Follow-up: } 14 \mathrm{~d}\end{array}$ & Total iron absorption, $\%$ & $\begin{array}{l}\text { Test: Fortified cereal with } \\
\text { calcium } 925 \mathrm{mg} / \mathrm{d} \\
\text { Ctrl: Low cereal with } \\
\text { calcium } 702 \mathrm{mg} / \mathrm{d}\end{array}$ & $\begin{array}{c}\text { Mean } \pm \text { SD } \\
4.2 \pm 3.5 \\
3.9 \pm 3.1\end{array}$ & Moderate \\
\hline \multirow[t]{2}{*}{$\begin{array}{l}\text { Agustina } \\
\text { (2013) }\end{array}$} & $\begin{array}{l}\text { East Jakarta, } \\
\text { Indonesia }\end{array}$ & $\begin{array}{c}\mathrm{RCT} \\
(\mathrm{N}=494)\end{array}$ & $5 \mathrm{y} ; 46 \%$ & $\begin{array}{l}21 \% \text { anemic; } \\
31 \% \text { iron } \\
\text { deficient }\end{array}$ & Intervention: $168 \mathrm{~d}$ & $\begin{array}{l}\text { Change in serum ferritin, } \\
\mu \mathrm{g} / \mathrm{L}\end{array}$ & $\begin{array}{l}\text { Test: Regular calcium } \\
\text { milk twice daily } \\
\quad(440 \mathrm{mg} / \mathrm{d}) ; \\
\text { Ctrl: Low calcium milk } \\
\text { twice daily }(50 \mathrm{mg} / \mathrm{d})\end{array}$ & $\begin{array}{c}\text { Med (IQR) } \\
-4.4(-15.7,1.6) \\
-4.0(-11.1,1.0)\end{array}$ & Moderate \\
\hline & & & & & & $\begin{array}{l}\text { Change in hemoglobin, } \\
\mathrm{g} / \mathrm{L}\end{array}$ & $\begin{array}{l}\text { Test } \\
\text { Ctrl }\end{array}$ & $\begin{array}{c}\text { Mean } \pm \text { SD } \\
\text { Test: }-1.5 \pm 8.8 \\
\text { Ctrl: }-1.9 \pm 7.7\end{array}$ & \\
\hline $\begin{array}{l}\text { Ames } \\
(1999)\end{array}$ & $\begin{array}{l}\text { Texas, } \\
\text { USA }\end{array}$ & $\begin{array}{l}\text { Case } \\
\text { crossover } \\
(\mathrm{N}=11)\end{array}$ & $\begin{array}{l}4.3 \mathrm{y} \\
45 \%\end{array}$ & NR & $\begin{array}{l}\text { Intervention: } 35 \mathrm{~d} \\
\text { Washout: } 15 \mathrm{~d}\end{array}$ & $\begin{array}{l}\text { Iron incorporation into } \\
\text { red blood cells, } \%\end{array}$ & $\begin{array}{l}\text { Test: High calcium diet } \\
\text { with calcium } 1180 \mathrm{mg} / \mathrm{d} \text {; } \\
\text { Ctrl: Low calcium diet } \\
\text { with calcium } 502 \mathrm{mg} / \mathrm{d}\end{array}$ & $\begin{array}{l}\text { Mean } \pm \text { SD } \\
\text { Test: } 7.9 \pm 5.5 \\
\text { Ctrl: } 6.9 \pm 4.2\end{array}$ & Moderate \\
\hline $\begin{array}{l}\text { Benkhedda } \\
\text { (2010) }\end{array}$ & $\begin{array}{l}\text { Ontario, } \\
\text { Canada }\end{array}$ & $\begin{array}{l}\text { Case } \\
\text { crossover } \\
(\mathrm{N}=13)\end{array}$ & $\begin{array}{l}30.9 \mathrm{y} \\
100 \%\end{array}$ & $\begin{array}{c}\text { Mean } \\
\text { hemoglobin: } \\
133 \mathrm{~g} / \mathrm{L} \\
\text { Mean ferritin: } \\
17.8 \mu \mathrm{g} / \mathrm{L}\end{array}$ & $\begin{array}{l}\text { Intervention: } 1 \mathrm{~d} \\
\text { Follow-up: } 14 \mathrm{~d}\end{array}$ & Total iron absorption, $\%$ & $\begin{array}{l}\text { Test: Calcium carbonate } \\
\text { (500mg) with meal; } \\
\text { Ctrl: Meal only }\end{array}$ & $\begin{array}{c}\text { Mean }(-\mathrm{SD},+\mathrm{SD}) \\
\text { Test: } 4.8(1.8,13.0) \\
\text { Ctrl: } 10.2(5.3,19.7)\end{array}$ & Low \\
\hline \multirow[t]{5}{*}{$\begin{array}{l}\text { Cook } \\
(1991)\end{array}$} & $\begin{array}{l}\text { Kansas, } \\
\text { USA }\end{array}$ & $\begin{array}{c}\text { Case } \\
\text { crossover } \\
(\mathrm{N}=61)\end{array}$ & $\begin{array}{l}21 \mathrm{y} \\
100 \%\end{array}$ & $\begin{array}{c}\text { Mean } \\
\text { hematocrit: } \\
41 \%, \\
\text { Mean ferritin: } \\
21 \mu \mathrm{g} / \mathrm{L}\end{array}$ & $\begin{array}{l}\text { Intervention: } 2 \mathrm{~d} \\
\text { Follow-up: } 16 \mathrm{~d}\end{array}$ & Iron absorption, \% & $\begin{array}{l}\text { Test: Calcium carbonate } \\
\text { (300mg) with meal; } \\
\text { Ctrl: Meal only }\end{array}$ & $\begin{array}{l}\text { Mean }(-\mathrm{SE},+\mathrm{SE}) \\
\text { Test: } 1.6(1.3,2.0) \\
\text { Ctrl: } 2.1(1.7,2.7)\end{array}$ & Low \\
\hline & & & & & & Iron absorption, \% & $\begin{array}{l}\text { Test: Calcium carbonate } \\
\text { (300mg) with water; } \\
\text { Ctrl: Water only }\end{array}$ & $\begin{array}{l}\text { Mean }(-\mathrm{SE},+\mathrm{SE}) \\
\text { Test: } 6.5(5.6,7.5) \\
\text { Ctrl: } 7.7(6.6,9.0)\end{array}$ & \\
\hline & & & 23 y; $89 \%$ & $\begin{array}{c}\text { Mean } \\
\text { hematocrit: } \\
40 \% ; \\
\text { Mean ferritin: } \\
24 \mu \mathrm{g} / \mathrm{L}\end{array}$ & & Iron absorption, \% & $\begin{array}{l}\text { Test: Calcium carbonate } \\
\text { (600mg) with meal; } \\
\text { Ctrl: Meal only }\end{array}$ & $\begin{array}{c}\text { Mean }(-\mathrm{SE},+\mathrm{SE}) \\
\text { Test: } 7.3(5.6,9.4) \\
\text { Ctrl: } 13.0(9.7,17.3)\end{array}$ & \\
\hline & & & & & & Iron absorption, \% & $\begin{array}{l}\text { Test: Calcium carbonate } \\
\text { (600mg) with water; } \\
\text { Ctrl: Water only }\end{array}$ & $\begin{array}{c}\text { Mean }(-\mathrm{SE},+\mathrm{SE}) \\
\text { Test: } 21.5(16.7, \\
27.6) \\
\text { Ctrl: } 18.0(14.1,23.0)\end{array}$ & \\
\hline & & & $\begin{array}{l}23 y \\
100 \%\end{array}$ & $\begin{array}{c}\text { Mean } \\
\text { hematocrit: } \\
46 \% \text {; } \\
\text { Mean ferritin: }\end{array}$ & & Iron absorption, $\%$ & $\begin{array}{l}\text { Test: Calcium carbonate } \\
\text { (600mg) with meal; } \\
\text { Ctrl: Meal only }\end{array}$ & $\begin{array}{l}\text { Mean }(-\mathrm{SE},+\mathrm{SE}) \\
\text { Test: } 3.3(2.4,4.5) \\
\text { Ctrl: } 3.9(2,8,5.3)\end{array}$ & \\
\hline
\end{tabular}




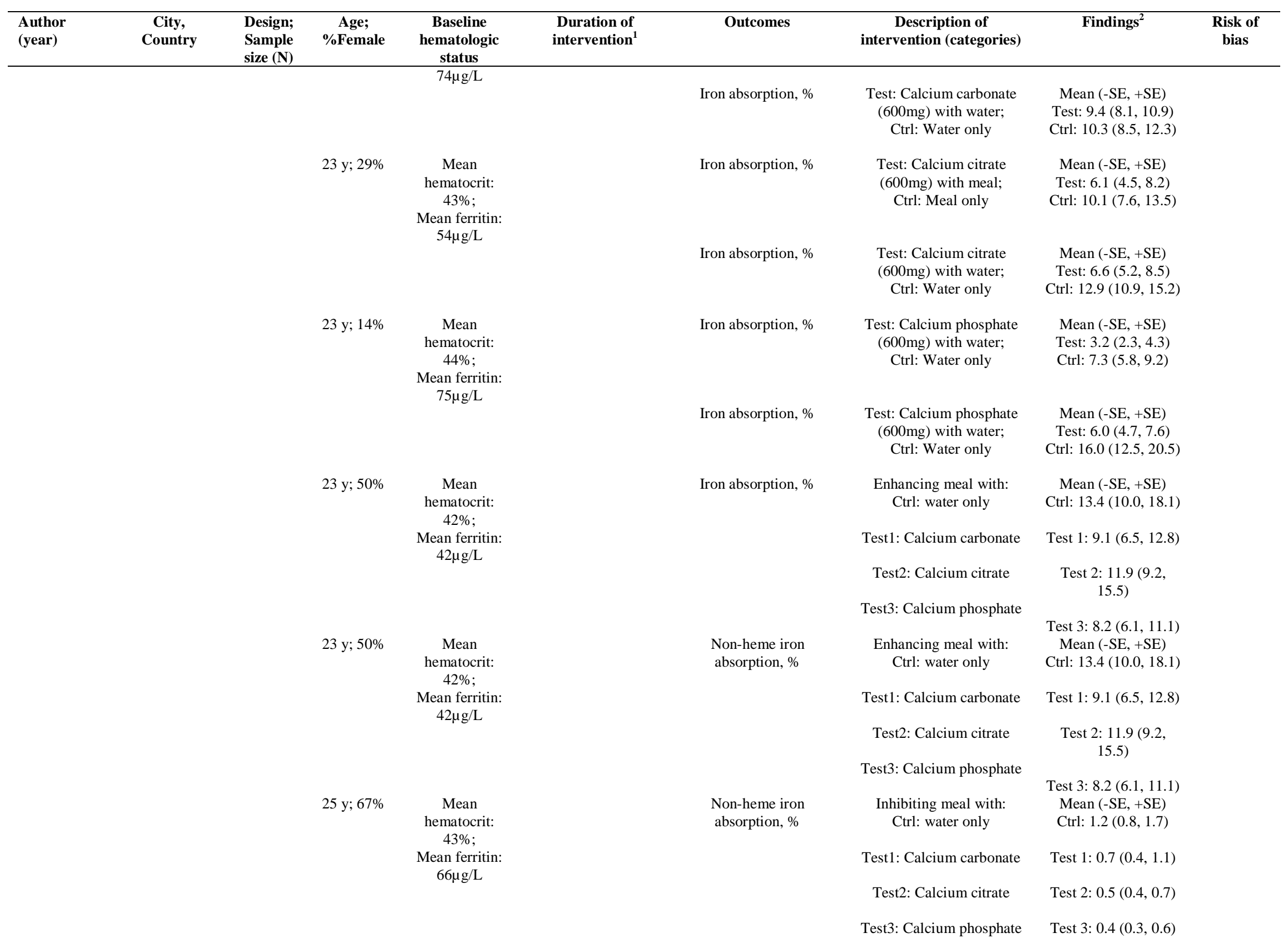




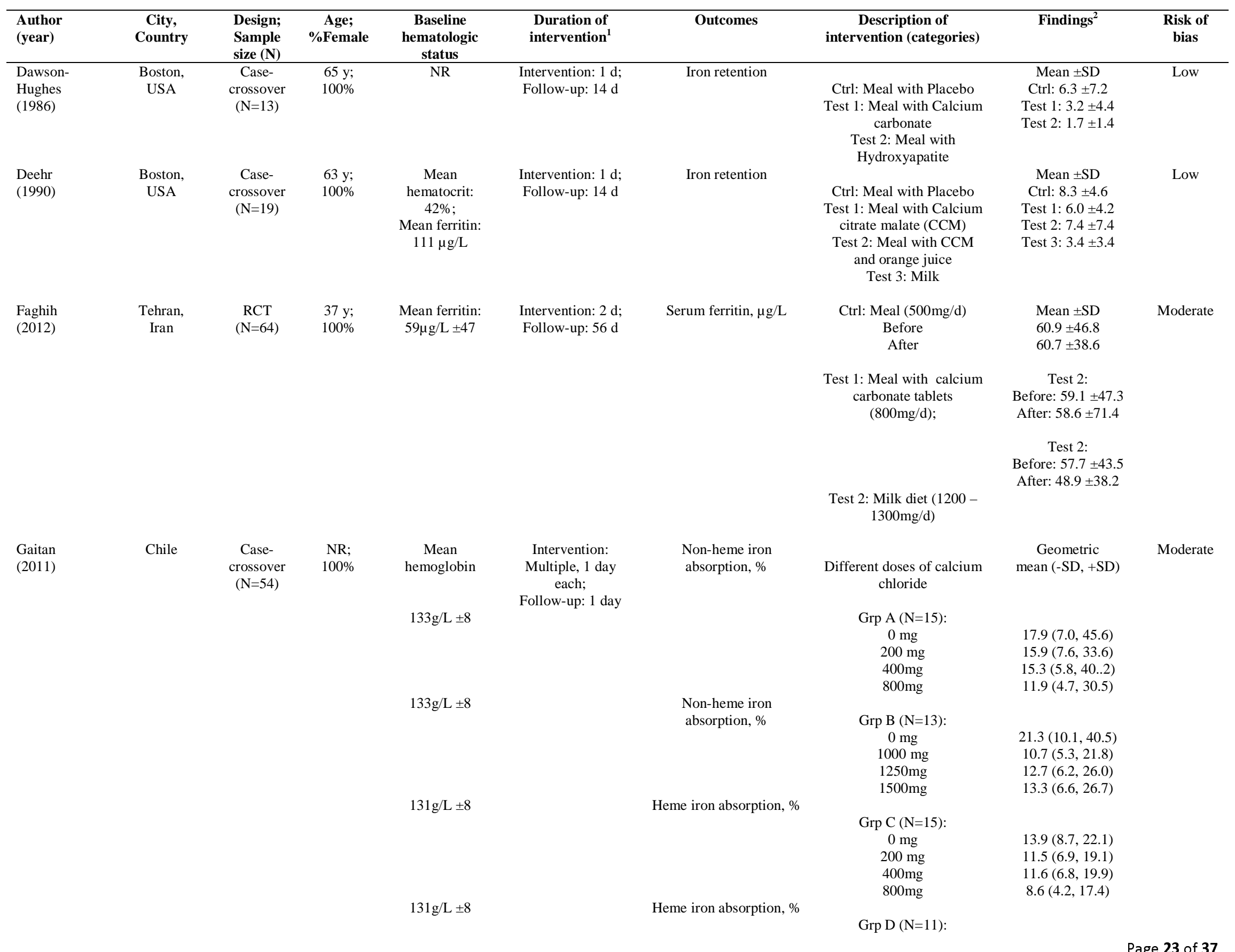

Page $\mathbf{2 3}$ of $\mathbf{3 7}$ 


\begin{tabular}{|c|c|c|c|c|c|c|c|c|c|}
\hline $\begin{array}{l}\text { Author } \\
\text { (year) }\end{array}$ & $\begin{array}{l}\text { City, } \\
\text { Country }\end{array}$ & $\begin{array}{l}\text { Design; } \\
\text { Sample } \\
\text { size }(\mathrm{N}) \\
\end{array}$ & $\begin{array}{c}\text { Age; } \\
\% \text { Female }\end{array}$ & $\begin{array}{c}\text { Baseline } \\
\text { hematologic } \\
\text { status }\end{array}$ & $\begin{array}{c}\text { Duration of } \\
\text { intervention }^{1}\end{array}$ & Outcomes & $\begin{array}{c}\text { Description of } \\
\text { intervention (categories) }\end{array}$ & Findings $^{2}$ & $\begin{array}{l}\text { Risk of } \\
\text { bias }\end{array}$ \\
\hline & & & & & & & $\begin{array}{c}0 \mathrm{mg} \\
500 \mathrm{mg} \\
600 \mathrm{mg} \\
700 \mathrm{mg}\end{array}$ & $\begin{array}{l}11.1(6.2,19.8) \\
9.0(4.7,17.0) \\
9.6(5.3,17.5) \\
10.1(5.8,17.5)\end{array}$ & \\
\hline $\begin{array}{l}\text { Galan } \\
(1991)\end{array}$ & $\begin{array}{l}\text { Paris, } \\
\text { France }\end{array}$ & $\begin{array}{l}\text { Case- } \\
\text { crossover } \\
(\mathrm{N}=13)\end{array}$ & $\begin{array}{l}32 \mathrm{y} \\
0 \%\end{array}$ & $\begin{array}{c}\text { Mean } \\
\text { hemoglobin: } \\
153 \mathrm{~g} / \mathrm{L}: \\
\text { Mean ferritin: } \\
128 \mu \mathrm{g} / \mathrm{L}\end{array}$ & $\begin{array}{l}\text { Intervention: } 1 \mathrm{~d} \\
\text { Follow-up: } 14 \mathrm{~d}\end{array}$ & $\begin{array}{l}\text { Non-heme iron } \\
\text { absorption, \% }\end{array}$ & $\begin{array}{c}\text { Ctrl: Meal alone } \\
\text { Test1: Meal + yoghurt } \\
\text { Test2: Meal + skimmed } \\
\text { milk }\end{array}$ & $\begin{array}{c}\text { Mean } \pm \text { SD } \\
2.2 \pm 4.9 \\
2.0 \pm 13.7 \\
2.1 \pm 6.3\end{array}$ & Moderate \\
\hline \multirow[t]{2}{*}{$\begin{array}{l}\text { Gleerup } \\
(1993)\end{array}$} & $\begin{array}{l}\text { Goteborg, } \\
\text { Sweden }\end{array}$ & $\begin{array}{l}\text { Case- } \\
\text { crossover } \\
(\mathrm{N}=21)\end{array}$ & $\begin{array}{l}38 \mathrm{y} \\
67 \%\end{array}$ & $\begin{array}{l}\text { Mean ferritin: } \\
50 \mu \mathrm{g} / \mathrm{L}\end{array}$ & $\begin{array}{l}\text { Intervention: } 1 \mathrm{~d} \\
\text { Follow-up: } 1 \mathrm{~d}\end{array}$ & Total iron absorption, $\%$ & $\begin{array}{c}\text { Ctrl: Meal alone } \\
\text { Test: Meal with milk and } \\
\text { cheese }\end{array}$ & $\begin{array}{c}\text { Mean } \pm \text { SEM } \\
13.8 \pm 3.6 \\
13.1 \pm 3.5\end{array}$ & High \\
\hline & & & & & & Total iron absorption, $\%$ & $\begin{array}{l}\text { Ctrl: Meal alone } \\
\text { Test: Meal with milk and } \\
\text { cheese }\end{array}$ & $\begin{array}{c}\text { Mean } \pm \text { SEM } \\
16.3 \pm 2.5 \\
16.5 \pm 2.5\end{array}$ & \\
\hline \multirow[t]{2}{*}{$\begin{array}{l}\text { Gleerup } \\
\text { (1995) }\end{array}$} & Sweden & $\begin{array}{l}\text { Case- } \\
\text { crossover } \\
(\mathrm{N}=21)\end{array}$ & $\begin{array}{l}29 y \\
100 \%\end{array}$ & NR & $\begin{array}{l}\text { Intervention: } 10 \mathrm{~d} \\
\text { Follow-up: } 4 \mathrm{w}\end{array}$ & $\begin{array}{l}\text { Non-heme iron } \\
\text { absorption, \% }\end{array}$ & $\begin{array}{l}\text { Test: Calcium at all meals } \\
\quad(937 \mathrm{mg} / \mathrm{d}) \\
\text { Ctrl: No calcium at lunch } \\
\quad \& \text { dinner }\end{array}$ & $\begin{array}{c}\text { Mean } \pm \text { SEM } \\
12.1 \pm 4.76 \\
15.9 \pm 2.2\end{array}$ & Moderate \\
\hline & & & & & & Heme iron absorption, $\%$ & $\begin{array}{l}\text { Test: Calcium at all meals } \\
\quad(937 \mathrm{mg} / \mathrm{d}) \\
\text { Ctrl: No calcium at lunch } \\
\quad \& \text { dinner }\end{array}$ & $\begin{array}{l}0.25 \pm 0.02 \\
0.33 \pm 0.02\end{array}$ & \\
\hline \multirow[t]{2}{*}{$\begin{array}{l}\text { Grinder- } \\
\text { Pederson } \\
(2004)\end{array}$} & Denmark & $\begin{array}{c}\mathrm{RCT} \\
(\mathrm{N}=14)\end{array}$ & $\begin{array}{l}24 y \\
100 \%\end{array}$ & $\begin{array}{l}\text { Non-anemic; no } \\
\text { excess iron }\end{array}$ & $\begin{array}{l}\text { Intervention: } 4 \mathrm{~d} \\
\text { Follow-up: } 18 \mathrm{~d}\end{array}$ & $\begin{array}{l}\text { Non-heme iron } \\
\text { absorption, } \% \text {, adjusted } \\
\text { to ferritin of } 40 \mu \mathrm{g} / \mathrm{L}\end{array}$ & $\begin{array}{c}\text { Diet (varying calcium/d): } \\
\text { Basic }(224 \mathrm{mg} / \mathrm{d}) \\
\text { Milk }(826 \mathrm{mg} / \mathrm{d}) \\
\text { Calcium lactate }(802 \\
\mathrm{mg} / \mathrm{d}) \\
\text { Milk mineral }(801 \mathrm{mg} / \mathrm{d})\end{array}$ & $\begin{array}{c}\text { Geom mean }(95 \% \\
\text { CI): } \\
2.6(1.5,4.4) \\
1.9(1.1,3.4) \\
2.3(1.6,3.3) \\
2.1(1.4,3.3)\end{array}$ & Moderate \\
\hline & & & & & & $\begin{array}{l}\text { Non-heme iron } \\
\text { absorption, \%, } \\
\text { unadjusted }\end{array}$ & $\begin{array}{c}\text { Diet (varying calcium/d): } \\
\text { Basic }(224 \mathrm{mg} / \mathrm{d}) \\
\text { Milk }(826 \mathrm{mg} / \mathrm{d}) \\
\text { Calcium lactate }(802 \\
\mathrm{mg} / \mathrm{d}) \\
\text { Milk mineral }(801 \mathrm{mg} / \mathrm{d})\end{array}$ & $\begin{array}{c}\text { Geom mean }(95 \% \\
\text { CI): } \\
7.4(5.3,10.5) \\
5.2(3.5,7.9) \\
6.7(5.0,8.9) \\
5.1(3.2,7.9)\end{array}$ & \\
\hline $\begin{array}{l}\text { Hallberg } \\
\text { (1991) }\end{array}$ & $\begin{array}{l}\text { Gothenburg, } \\
\text { Sweden }\end{array}$ & $\begin{array}{c}\text { Case- } \\
\text { crossover } \\
(\mathrm{N}=126)\end{array}$ & $\mathrm{NR} ; 36 \%$ & NR & $\begin{array}{l}\text { Intervention: } 4 \mathrm{~d} \\
\text { Follow-up: } 18 \mathrm{~d}\end{array}$ & Heme iron absorption & $\begin{array}{c}\text { Calcium added to wheat } \\
\text { flour } \\
\text { Series 1: } \\
0 \mathrm{mg}\end{array}$ & $22.0 \pm 3.6$ & Moderate \\
\hline
\end{tabular}




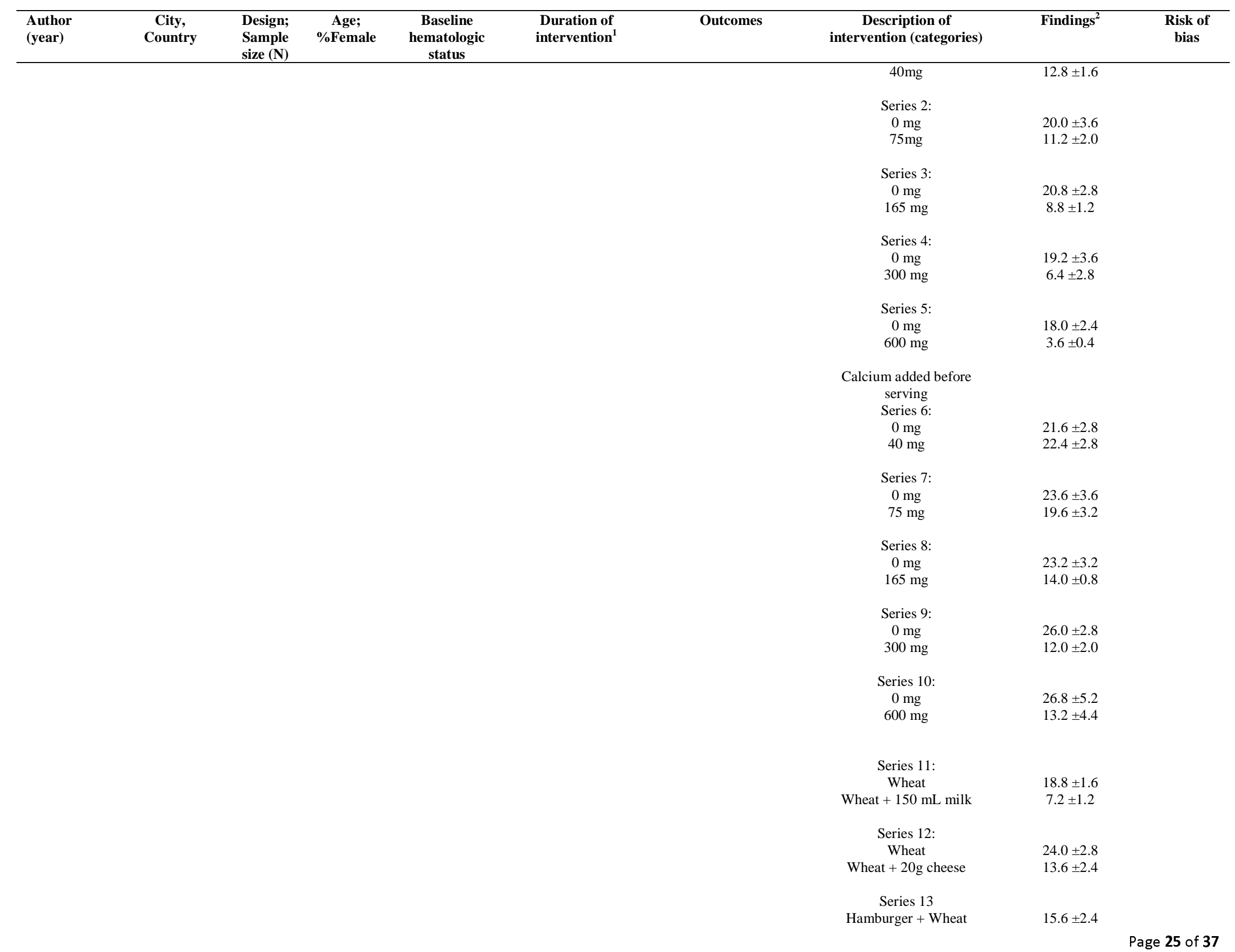




\begin{tabular}{|c|c|c|c|c|c|c|c|c|c|}
\hline $\begin{array}{l}\text { Author } \\
\text { (year) }\end{array}$ & $\begin{array}{l}\text { City, } \\
\text { Country }\end{array}$ & $\begin{array}{l}\text { Design; } \\
\text { Sample } \\
\text { size }(\mathrm{N}) \\
\end{array}$ & $\begin{array}{c}\text { Age; } \\
\% \text { Female }\end{array}$ & $\begin{array}{c}\text { Baseline } \\
\text { hematologic } \\
\text { status }\end{array}$ & $\begin{array}{c}\text { Duration of } \\
\text { intervention }^{1}\end{array}$ & Outcomes & $\begin{array}{c}\text { Description of } \\
\text { intervention (categories) }\end{array}$ & Findings $^{2}$ & $\begin{array}{l}\text { Risk of } \\
\text { bias }\end{array}$ \\
\hline & & & & & & & $\begin{array}{c}\text { Hamburger }+ \text { Wheat }+ \\
165 \mathrm{mg} \mathrm{Ca}\end{array}$ & $11.6 \pm 2.0$ & \\
\hline \multirow[t]{2}{*}{$\begin{array}{l}\text { Hallberg } \\
\text { (1993) }\end{array}$} & $\begin{array}{l}\text { Goteborg, } \\
\text { Sweden }\end{array}$ & $\begin{array}{c}\mathrm{RCT} \\
(\mathrm{N}=28)\end{array}$ & NR: $57 \%$ & NR & $\begin{array}{l}\text { Intervention: } 1 \mathrm{~d} \\
\text { Follow-up: } 1 \mathrm{~d}\end{array}$ & Heme iron absorption, $\%$ & $\begin{array}{c}\text { Test: Meat-containing } \\
\text { meal with } 165 \mathrm{mg} \text { calcium } \\
\text { chloride; } \\
\text { Ctrl: Meat containing meal } \\
\text { alone }\end{array}$ & $\begin{array}{c}\text { Mean } \pm \text { SE } \\
\text { Test: } 12.1 \pm 1.5 \\
\text { Ctrl: } 22.7 \pm 3.9\end{array}$ & High \\
\hline & & & & & & & $\begin{array}{l}\text { Test: Non-meat-containing } \\
\text { meal with } 165 \mathrm{mg} \text { calcium } \\
\text { chloride; } \\
\text { Ctrl: Meat containing meal } \\
\text { alone }\end{array}$ & $\begin{array}{c}\text { Mean } \pm \text { SE } \\
\text { Test: } 11.2 \pm 1.7 \\
\text { Ctrl: } 20.3 \pm 2.3\end{array}$ & \\
\hline \multirow[t]{3}{*}{$\begin{array}{l}\text { Ilich-Ernst } \\
\text { (1998) }\end{array}$} & $\begin{array}{l}\text { Cincinnati, } \\
\text { USA }\end{array}$ & $\begin{array}{l}\mathrm{RCT} ; \\
(\mathrm{N}=354)\end{array}$ & $\begin{array}{l}10.8 \mathrm{y} \\
100 \%\end{array}$ & $\begin{array}{l}\text { Mean ferritin: } \\
29.2 \mu \mathrm{g} / \mathrm{L}\end{array}$ & $\begin{array}{l}\text { Intervention: } 4 \text { y } \\
\text { Follow-up: } 4 \text { y }\end{array}$ & Hemoglobin, g/L, year 4 & $\begin{array}{c}\text { Test: Calcium citrate } \\
\text { malate, } 1000 \mathrm{mg} / \mathrm{d} \\
\text { Ctrl: Placebo }\end{array}$ & $\begin{array}{l}\text { Mean } \pm \text { SD } \\
\text { Test: } 132 \pm 9 \\
\text { Ctrl: } 134 \pm 8\end{array}$ & Moderate \\
\hline & & & & & & $\begin{array}{l}\text { Serum ferritin, } \mu \mathrm{g} / \mathrm{L}, \text { in } \\
\text { lactating women }(\mathrm{N}=76)\end{array}$ & Baseline - & $\begin{array}{c}\text { Mean } \pm \text { SD } \\
\text { Test: } \\
\text { Baseline }-29.1 \pm 1.3 \\
\text { Year } 1-31.1 \pm 1.5 \\
\text { Year 2 }-31.1 \pm 1.6 \\
\text { Year 3 }-30.6 \pm 2.0 \\
\text { Year 4 }-29.5 \pm 1.9\end{array}$ & \\
\hline & & & & & & & & $\begin{array}{c}\text { Ctrl: } \\
\text { Baseline }-29.3 \pm 1.4 \\
\text { Year 1 }-33.8 \pm 1.7 \\
\text { Year 2-32.3 } \pm 1.4 \\
\text { Year 3 }-30.9 \pm 1.5 \\
\text { Year 4-29.5 } \pm 1.6\end{array}$ & \\
\hline \multirow[t]{4}{*}{$\begin{array}{l}\text { Kalkwarf } \\
(1998)\end{array}$} & $\begin{array}{l}\text { Cincinnati, } \\
\text { USA }\end{array}$ & $\begin{array}{l}\text { RCT: } \\
(\mathrm{N}=158)\end{array}$ & $\begin{array}{l}31 \mathrm{y} \\
100 \%\end{array}$ & $\begin{array}{l}\text { Mean } \\
\text { hemoglobin: } \\
133 \mathrm{~g} / \mathrm{L}\end{array}$ & $\begin{array}{l}\text { Intervention: } 26 \mathrm{wk} \\
\text { Follow-up: } 26 \mathrm{wk}\end{array}$ & $\begin{array}{l}\text { Serum ferritin, } \mu \mathrm{g} / \mathrm{L} \text {, in } \\
\text { lactating women }(\mathrm{N}=76)\end{array}$ & $\begin{array}{c}\text { Test: Calcium } \\
\text { supplements } 500 \mathrm{mg} \text { twice } \\
\text { daily } \\
\text { Ctrl: None }\end{array}$ & $\begin{array}{c}\text { Geom Mean }(-S D, \\
\text { +SD) } \\
\text { Test: } \\
28.4(12.3,51.0) \\
\text { Ctrl: } \\
27.5(9.3,55 .))\end{array}$ & Low \\
\hline & & & & & & $\begin{array}{l}\text { Hemoglobin, g/L, in } \\
\text { lactating women }(\mathrm{N}=76)\end{array}$ & & $\begin{array}{l}\text { Mean } \pm \text { SD } \\
\text { Test: } 133 \pm 7 \\
\text { Ctrl: } 130 \pm 6\end{array}$ & \\
\hline & & & & & & $\begin{array}{l}\text { Hemoglobin, g/L, in non- } \\
\text { lactating women }(\mathrm{N}=82)\end{array}$ & & $\begin{array}{l}\text { Test: } 129 \pm 7 \\
\text { Ctrl: } 130 \pm 8\end{array}$ & \\
\hline & & & & & & $\begin{array}{l}\mathrm{MCV}, \mathrm{g} / \mathrm{L} \text {, in lactating } \\
\text { women }(\mathrm{N}=76)\end{array}$ & & $\begin{array}{l}\text { Test: } 90 \pm 4 \\
\text { Ctrl: } 88 \pm 4\end{array}$ & \\
\hline
\end{tabular}




\begin{tabular}{|c|c|c|c|c|c|c|c|c|c|}
\hline $\begin{array}{l}\text { Author } \\
\text { (year) }\end{array}$ & $\begin{array}{c}\text { City, } \\
\text { Country }\end{array}$ & $\begin{array}{l}\text { Design; } \\
\text { Sample } \\
\text { size (N) }\end{array}$ & $\begin{array}{c}\text { Age; } \\
\% \text { Female }\end{array}$ & $\begin{array}{c}\text { Baseline } \\
\text { hematologic } \\
\text { status }\end{array}$ & $\begin{array}{c}\text { Duration of } \\
\text { intervention }^{1}\end{array}$ & Outcomes & $\begin{array}{c}\text { Description of } \\
\text { intervention (categories) }\end{array}$ & Findings $^{2}$ & $\begin{array}{c}\text { Risk of } \\
\text { bias }\end{array}$ \\
\hline & & & & & & $\begin{array}{c}\mathrm{MCV}, \mathrm{g} / \mathrm{L}, \text { in non- } \\
\text { lactating women }(\mathrm{N}=82)\end{array}$ & & $\begin{array}{l}\text { Test: } 88 \pm 4 \\
\text { Ctrl: } 88 \pm 4\end{array}$ & \\
\hline \multirow[t]{3}{*}{$\begin{array}{l}\text { Minihane } \\
\text { (1998) }\end{array}$} & $\begin{array}{l}\text { Norwich, } \\
\text { UK }\end{array}$ & $\begin{array}{c}\mathrm{RCT} \\
(\mathrm{N}=24)\end{array}$ & $44 \mathrm{y} ; 71 \%$ & $\begin{array}{l}\text { Non-anemic; } \\
\text { Mean ferritin: } \\
44 \mu \mathrm{g} / \mathrm{l}\end{array}$ & Intervention: $183 \mathrm{~d}$ & Hemoglobin, g/L & $\begin{array}{l}\text { Test: Calcium carbonate } \\
\text { (1200mg) supplements; } \\
\text { Ctrl: None }\end{array}$ & $\begin{array}{l}\text { Mean (SE) } \\
\text { Test: } 136(4) \\
\text { Ctrl: } 139(4)\end{array}$ & Moderate \\
\hline & & & & & & Serum ferritin, $\mu \mathrm{g} / \mathrm{L}$ & & $\begin{array}{l}\text { Test: } 50(7) \\
\text { Ctrl: } 38(7)\end{array}$ & \\
\hline & & & & & & $\begin{array}{l}\text { Zinc protoporphyrin } \\
\text { (ZPP), } \mu \mathrm{g} / \mathrm{L} \\
\text { Non-heme iron } \\
\text { absorption, \% }\end{array}$ & & $\begin{array}{l}\text { Test: } 226(18) \\
\text { Ctrl: } 277(19) \\
\text { Test: } 4.7(1.4) \\
\text { Ctrl: } 15.8(2.1)\end{array}$ & \\
\hline \multirow[t]{2}{*}{$\begin{array}{l}\text { Miranda } \\
\text { (2014) }\end{array}$} & $\begin{array}{l}\text { Sucre, } \\
\text { Bolivia }\end{array}$ & $\begin{array}{c}\text { RCT } \\
(\mathrm{N}=179)\end{array}$ & $\begin{array}{l}8.3 \mathrm{y} \\
44 \%\end{array}$ & $\underset{>>83 \mathrm{~g} / \mathrm{L}}{\text { Hemoglobin }}$ & Intervention: $90 \mathrm{~d}$ & Hemoglobin, g/L & $\begin{array}{c}\text { Test: } 700 \mathrm{mg} \text { Calcium with } \\
\text { iron; } \\
\text { Ctrl: Iron only }\end{array}$ & $\begin{array}{l}\text { Mean } \pm \text { SD } \\
\text { Test: } 148 \pm 7 \\
\text { Ctrl: } 147 \pm 8\end{array}$ & Moderate \\
\hline & & & & & & Serum ferritin, $\mu \mathrm{g} / \mathrm{L}$ & & $\begin{array}{l}\text { Mean }(-\mathrm{SD},+\mathrm{SD}) \\
\text { Test: } 35(24-52) \\
\text { Ctrl: } 38(25-57)\end{array}$ & \\
\hline \multirow[t]{8}{*}{$\begin{array}{l}\text { Mølgaard } \\
(2005)\end{array}$} & $\begin{array}{c}\text { Frederiksberg } \\
\& \\
\text { Copenhagen, } \\
\text { Denmark }\end{array}$ & $\begin{array}{c}\mathrm{RCT} \\
(\mathrm{N}=113)\end{array}$ & $\begin{array}{l}13 \mathrm{y} \\
100 \%\end{array}$ & $\begin{array}{l}\text { Non-anemic; } \\
\text { Mean ferritin: } \\
27 \mu \mathrm{g} / \mathrm{l}\end{array}$ & Intervention: $52 \mathrm{wk}$ & $\begin{array}{l}\text { Hemoglobin, } g / L \text { in low } \\
\text { dietary Ca group }\end{array}$ & $\begin{array}{l}\text { Test: Calcium } \\
\text { supplements - 500mg/d; } \\
\text { Ctrl: Placebo }\end{array}$ & $\begin{array}{c}\text { Mean }(95 \% \text { CI }) \\
\text { Test:135 }(132,138) \\
\text { Ctrl: } 134(131,137)\end{array}$ & Low \\
\hline & & & & & & $\begin{array}{l}\text { Hemoglobin, } \mathrm{g} / \mathrm{L} \text { in } \\
\text { medium dietary } \mathrm{Ca} \text { group }\end{array}$ & & $\begin{array}{l}\text { Test: } 137(134,139) \\
\text { Ctrl: } 135(132,137)\end{array}$ & \\
\hline & & & & & & $\begin{array}{l}\text { Serum ferritin, } \mu \mathrm{g} / \mathrm{L}, \text { in } \\
\text { low dietary Ca group }\end{array}$ & & $\begin{array}{c}\text { Test: } 24.3(20.3, \\
29.2) \\
\text { Ctrl: } 26.9(22.6,31.9)\end{array}$ & \\
\hline & & & & & & $\begin{array}{l}\text { Serum ferritin, } \mu \mathrm{g} / \mathrm{L} \text {, in } \\
\text { medium dietary Ca group }\end{array}$ & & $\begin{array}{c}\text { Test: } 26.7(22.3, \\
32.1) \\
\text { Ctrl: } 24.9(20.9,29.7)\end{array}$ & \\
\hline & & & & & & $\begin{array}{l}\mathrm{sTfR}^{3}, \mathrm{mg} / \mathrm{L}, \text { in low } \\
\text { dietary Ca group }\end{array}$ & & $\begin{array}{l}\text { Test: } 4.0(3.7,4.4) \\
\text { Ctrl: } 4.1(3.8,4.5)\end{array}$ & \\
\hline & & & & & & $\begin{array}{l}\mathrm{sTfR}^{3}, \mathrm{mg} / \mathrm{L}, \text { in medium } \\
\text { dietary Ca group }\end{array}$ & & $\begin{array}{l}\text { Test: } 4.1(3.8,4.5) \\
\text { Ctrl: } 4.5(4.2,4.9)\end{array}$ & \\
\hline & & & & & & $\begin{array}{l}\text { sTfR-ferritin index, in } \\
\text { low dietary Ca group }\end{array}$ & & $\begin{array}{l}\text { Test: } 163(137,194) \\
\text { Ctrl: } 145(123,171)\end{array}$ & \\
\hline & & & & & & $\begin{array}{l}\text { sTfR-ferritin index, in } \\
\text { medium dietary Ca group }\end{array}$ & & $\begin{array}{l}\text { Test: } 156(127,192) \\
\text { Ctrl: } 177(145,217)\end{array}$ & \\
\hline
\end{tabular}




\begin{tabular}{|c|c|c|c|c|c|c|c|c|c|}
\hline $\begin{array}{l}\text { Author } \\
\text { (year) }\end{array}$ & $\begin{array}{l}\text { City, } \\
\text { Country }\end{array}$ & $\begin{array}{l}\text { Design; } \\
\text { Sample } \\
\text { size (N) }\end{array}$ & $\begin{array}{c}\text { Age; } \\
\% \text { Female }\end{array}$ & $\begin{array}{c}\text { Baseline } \\
\text { hematologic } \\
\text { status }\end{array}$ & $\begin{array}{c}\text { Duration of } \\
\text { intervention }^{1}\end{array}$ & Outcomes & $\begin{array}{c}\text { Description of } \\
\text { intervention (categories) }\end{array}$ & Findings $^{2}$ & $\begin{array}{l}\text { Risk of } \\
\text { bias }\end{array}$ \\
\hline \multirow[t]{2}{*}{$\begin{array}{l}\text { Monsen } \\
\text { (1976) }\end{array}$} & $\begin{array}{l}\text { Washington, } \\
\text { USA }\end{array}$ & $\begin{array}{l}\text { Case- } \\
\text { crossover } \\
(\mathrm{N}=21)\end{array}$ & $\begin{array}{l}25 y \\
100 \%\end{array}$ & NR & $\begin{array}{l}\text { Intervention: } 1 \mathrm{~d} \\
\text { Follow-up: } 14 \mathrm{~d}\end{array}$ & Total iron absorption, $\%$ & $\begin{array}{l}\text { Ctrl: Meal alone } \\
\text { Test: Meal with Calcium } \\
\text { phosphate salts }\end{array}$ & $\begin{array}{c}\text { Mean } \pm \text { SD } \\
\text { Test: } 1.6 \pm 2.3 \\
\text { Ctrl: } 2.6 \pm 2.7\end{array}$ & Moderate \\
\hline & & & & & & $\begin{array}{l}\text { Non-heme iron } \\
\text { absorption, \% }\end{array}$ & & $\begin{array}{c}\text { Mean } \pm \text { SD } \\
\text { Test: } 6.8 \pm 6.5 \\
\text { Ctrl: } 12.1 \pm 8.3\end{array}$ & \\
\hline $\begin{array}{l}\text { Reddy } \\
\text { (1997) }\end{array}$ & $\begin{array}{l}\text { Kansas, } \\
\text { USA }\end{array}$ & $\begin{array}{l}\text { Case- } \\
\text { crossover } \\
(\mathrm{N}=14)\end{array}$ & $25 \mathrm{y} ; 57 \%$ & $\begin{array}{l}\text { Mean ferritin: } \\
50 \mu \mathrm{g} / \mathrm{L}\end{array}$ & $\begin{array}{l}\text { Intervention: } 2 \mathrm{~d} \text {; } \\
\text { Follow-up: } 14 \mathrm{~d} \text {; } \\
\text { Washout: } 5 \mathrm{~d}\end{array}$ & $\begin{array}{l}\text { Non-heme iron } \\
\text { absorption, \% }\end{array}$ & $\begin{array}{c}\text { Four diets: } \\
\text { 1. Standard hamburger } \\
\text { meal } \\
\text { 2. Self }- \text { selected } \\
(685 \mathrm{mg} / \mathrm{d}) \\
\text { 3. High calcium } \\
(1281 \mathrm{mg} / \mathrm{d}) ; \\
\text { 4. Low calcium }(280 \mathrm{mg} / \mathrm{d})\end{array}$ & $\begin{array}{c}\text { Standard: } 4.8(3.7, \\
6.2) \\
\text { Self: } 5.0(4.1,6.2) \\
\text { High Ca: } 4.7(3.8, \\
5.9) \\
\text { Low Ca: } 5.8(4.7, \\
7.3)\end{array}$ & Moderate \\
\hline \multirow[t]{2}{*}{$\begin{array}{l}\text { Reddy } \\
(2000)\end{array}$} & USA & $\begin{array}{c}\mathrm{RCT} \\
(\mathrm{N}=86)\end{array}$ & $26 \mathrm{y} ; 40 \%$ & $\begin{array}{l}\text { Mean ferritin: } \\
41 \mu \mathrm{g} / \mathrm{L}\end{array}$ & $\begin{array}{l}\text { Intervention: } 2 \mathrm{~d} \text {; } \\
\text { Follow-up: } 14 \mathrm{~d}\end{array}$ & $\begin{array}{l}\text { Non-heme iron } \\
\text { absorption, \% }\end{array}$ & $\begin{array}{c}\text { Test: } 25 \text { different meals }{ }^{4} \\
22 \mathrm{mg} \mathrm{Ca} \\
589 \mathrm{mg} \mathrm{Ca}\end{array}$ & $\begin{array}{c}\text { Geom mean }(-\mathrm{SE}, \\
+\mathrm{SE}) \\
11.5(9.6,15.2) \\
2.6(2.0,3.5)\end{array}$ & Low \\
\hline & & & & & & Serum ferritin, $\mu \mathrm{g} / \mathrm{L}$ & $\begin{array}{c}22 \mathrm{mg} \mathrm{Ca} \\
589 \mathrm{mg} \mathrm{Ca}\end{array}$ & $\begin{array}{l}28(22,36) \\
34(24,39)\end{array}$ & \\
\hline \multirow[t]{5}{*}{$\begin{array}{l}\text { Rios-Castillo } \\
\text { (2014) }\end{array}$} & $\begin{array}{l}\text { Santiago, } \\
\text { Chile }\end{array}$ & $\begin{array}{c}\mathrm{RCT} \\
(\mathrm{N}=26)\end{array}$ & $\begin{array}{l}39 \mathrm{y} \\
100 \%\end{array}$ & $\begin{array}{l}\text { Non-anemic; } \\
\text { non-iron } \\
\text { deficient }\end{array}$ & Intervention: $34 \mathrm{~d}$ & Hemoglobin, g/L & $\begin{array}{l}\text { Test: Calcium }(600 \mathrm{mg}) \\
\text { supplements with iron; } \\
\text { Ctrl: Iron only }\end{array}$ & $\begin{array}{l}\text { Mean } \pm \text { SD } \\
\text { Test: } 141 \pm 11 \\
\text { Ctrl: } 145 \pm 11\end{array}$ & Moderate \\
\hline & & & & & & $\begin{array}{l}\text { Mean corpuscular } \\
\text { volume (MCV), fL }\end{array}$ & & $\begin{array}{l}\text { Test: } 86 \pm 5 \\
\text { Ctrl: } 86 \pm 4\end{array}$ & \\
\hline & & & & & & $\begin{array}{l}\text { Zinc protoporphyrin, } \\
\mu \mathrm{g} / \mathrm{dL}\end{array}$ & & $\begin{array}{c}\text { Geom mean }(-S D \\
\text { +SD) } \\
\text { Test: } 65(52,80) \\
\text { Ctrl: } 60(47,78)\end{array}$ & \\
\hline & & & & & & Serum ferritin, $\mu \mathrm{g} / \mathrm{L}$ & & $\begin{array}{c}\text { Test: } 18.5(7.3,46.8) \\
\text { Ctrl: } 24.9(14,44.2)\end{array}$ & \\
\hline & & & & & & $\begin{array}{c}\text { Heme iron } \\
\text { bioavailability, } \% \text { of } \\
\text { absorption }\end{array}$ & & $\begin{array}{l}\text { Test: } 26(15.5,43.6) \\
\text { Ctrl: } 25.1(16.5,38.3)\end{array}$ & \\
\hline $\begin{array}{l}\text { Roughead } \\
\text { (2002) }\end{array}$ & USA & $\begin{array}{l}\text { Case- } \\
\text { crossover } \\
(\mathrm{N}=17)\end{array}$ & $34 \mathrm{y} ; 53 \%$ & $\begin{array}{l}\text { Non-anemic; } \\
\text { no excess iron }\end{array}$ & $\begin{array}{l}\text { Intervention: } 1 \text { day; } \\
\text { Follow-up: } 15 \mathrm{~d} \text {; } \\
\text { Washout: } 28 \mathrm{~d}\end{array}$ & $\begin{array}{l}\text { Non-heme iron } \\
\text { absorption, \% }\end{array}$ & $\begin{array}{l}\text { Test: High iron, low } \\
\text { calcium meal with } 127 \mathrm{mg} \\
\text { calcium supplements; } \\
\text { Ctrl: Test intervention } \\
\text { with no calcium } \\
\text { supplements }\end{array}$ & $\begin{array}{c}\text { Mean }(-\mathrm{SD},+\mathrm{SD}) \\
\text { Test: } 7.4(3.4,16.1) \\
\text { Ctrl: } 6.6(3.0,14.4)\end{array}$ & Moderate \\
\hline
\end{tabular}




\begin{tabular}{|c|c|c|c|c|c|c|c|c|c|}
\hline $\begin{array}{l}\text { Author } \\
\text { (year) }\end{array}$ & $\begin{array}{l}\text { City, } \\
\text { Country }\end{array}$ & $\begin{array}{l}\text { Design; } \\
\text { Sample } \\
\text { size }(\mathrm{N}) \\
\end{array}$ & $\begin{array}{c}\text { Age; } \\
\% \text { Female }\end{array}$ & $\begin{array}{c}\text { Baseline } \\
\text { hematologic } \\
\text { status }\end{array}$ & $\begin{array}{c}\text { Duration of } \\
\text { intervention }^{1}\end{array}$ & Outcomes & $\begin{array}{c}\text { Description of } \\
\text { intervention (categories) }\end{array}$ & Findings $^{2}$ & $\begin{array}{l}\text { Risk of } \\
\text { bias }\end{array}$ \\
\hline & & & & & & $\begin{array}{l}\text { Heme iron absorption, } \% \\
\text { Serum ferritin, } \mu \mathrm{g} / \mathrm{L}\end{array}$ & & $\begin{array}{c}\text { Test: } 16.2(11.8, \\
22.4) \\
\text { Ctrl: } 14.5(9.7,21.7) \\
\\
\text { Test: } 55(22,138) \\
\text { Ctrl: } 54(21,143)\end{array}$ & \\
\hline $\begin{array}{l}\text { Roughead } \\
\text { (2005) }\end{array}$ & $\begin{array}{l}\text { North Dakota, } \\
\text { USA }\end{array}$ & $\begin{array}{l}\text { Case- } \\
\text { crossover } \\
(\mathrm{N}=27)\end{array}$ & 38 y; NR & $\begin{array}{l}\text { Non-anemic; no } \\
\text { excess iron }\end{array}$ & $\begin{array}{l}\text { Intervention: } 1 \text { day; } \\
\text { Follow-up } 14 \mathrm{~d} \text {; } \\
\text { Washout: } 42 \mathrm{~d}\end{array}$ & $\begin{array}{c}\text { Non-heme iron } \\
\text { absorption, } \%\end{array}$ & $\begin{array}{c}\text { Experiment A: } \\
\text { Test: Calcium } \\
\text { supplements } 450 \mathrm{mg} \text { with } \\
\text { high iron, moderate } \\
\text { calcium meal with } 360 \mathrm{mg} \\
\text { calcium; Ctrl: Meal only }\end{array}$ & $\begin{array}{l}\text { Mean }(-\mathrm{SE},+\mathrm{SE}) \\
\text { Test: } 0.4(0.3,0.5) \\
\text { Ctrl: } 0.5(0.4,0.6)\end{array}$ & Moderate \\
\hline & & & & & & $\begin{array}{c}\begin{array}{c}\text { Non-heme iron } \\
\text { absorption, } \%\end{array} \\
\text { Heme iron absorption, \% }\end{array}$ & $\begin{array}{c}\text { Experiment B: } \\
\text { Test: Calcium } \\
\text { supplements } 450 \mathrm{mg} \text { with } \\
\text { high iron, low calcium } \\
\text { meal with } 60 \mathrm{mg} \text { calcium; } \\
\text { Ctrl: Meal only }\end{array}$ & $\begin{array}{l}\text { Test: } 6(5,8) \\
\text { Ctrl: } 8(7,11) \\
\text { Test: } 16(14,19) \\
\text { Ctrl: } 22(20,25)\end{array}$ & \\
\hline $\begin{array}{l}\text { Snedeker } \\
(1982)\end{array}$ & $\begin{array}{l}\text { Wisconsin, } \\
\text { USA }\end{array}$ & $\begin{array}{l}\text { Case- } \\
\text { crossover } \\
(\mathrm{N}=9)\end{array}$ & $\begin{array}{l}\mathrm{NR} ; \\
0 \%\end{array}$ & NR & $\begin{array}{l}\text { Intervention: } 12 \mathrm{~d} \\
\text { Follow-up: } 12 \mathrm{~d}\end{array}$ & $\begin{array}{l}\text { Serum ferritin, } \mu \mathrm{g} / \mathrm{L} \text { in } \\
\text { adult males receiving } \\
\text { high phosphate diets }\end{array}$ & $\begin{array}{l}\text { Test: High calcium } \\
\text { Ctrl: Moderate calcium }\end{array}$ & $\begin{array}{l}\text { Mean } \pm \text { SD } \\
\text { Test: } 96 \pm 41 \\
\text { Ctrl: } 104 \pm 50\end{array}$ & Low \\
\hline $\begin{array}{l}\text { Sokoll } \\
(1992)\end{array}$ & $\begin{array}{l}\text { Boston, } \\
\text { USA }\end{array}$ & $\begin{array}{c}\mathrm{RCT} \\
(\mathrm{N}=109)\end{array}$ & $\begin{array}{l}32 \mathrm{y} \\
100 \%\end{array}$ & $\begin{array}{l}\text { Hematocrit } \\
\geq 32 \%\end{array}$ & $\begin{array}{l}\text { Intervention: } 12 \mathrm{wk} \\
\text { Follow-up: } 12 \mathrm{wk}\end{array}$ & $\begin{array}{c}\text { Change in plasma } \\
\text { ferritin, } \mu \mathrm{g} / \mathrm{L} \\
\text { Change in hemoglobin, } \\
\mathrm{g} / \mathrm{L}\end{array}$ & $\begin{array}{l}\text { Test: Ca supplements, } \\
\text { 250mg twice } \\
\text { Ctrl: None }\end{array}$ & $\begin{array}{l}\text { Test: }-2.2 \pm 38.4 \\
\text { Ctrl: } 2.6 \pm 39.7 \\
\text { Test: } 1.0 \pm 4.7 \\
\text { Ctrl: } 0.6 \pm 4.7\end{array}$ & Low \\
\hline $\begin{array}{l}\text { Walczyk } \\
\text { (2014) }\end{array}$ & $\begin{array}{l}\text { Bangalore, } \\
\text { India }\end{array}$ & $\begin{array}{l}\text { Case- } \\
\text { crossover } \\
(\mathrm{N}=96)\end{array}$ & $\begin{array}{l}\text { Iron- } \\
\text { replete } \\
\text { subgroup: } \\
9 \text { y; } 40 \%\end{array}$ & $\begin{array}{c}\text { Mean } \\
\text { hemoglobin: } \\
126 \mathrm{~g} / \mathrm{L} \pm 4 ; \\
\text { Mean ferritin: } \\
48 \mu \mathrm{g} / \mathrm{L} \pm 20\end{array}$ & $\begin{array}{l}\text { Intervention: } 1 \text { day; } \\
\text { Washout: } 14 \mathrm{~d}\end{array}$ & $\begin{array}{l}\text { Iron absorption, } \% \text {, in } \\
\text { iron-replete children }\end{array}$ & $\begin{array}{c}\text { Ctrl: Drink } \\
\text { Test 1: Drink with 100mg } \\
\text { Ca } \\
\text { Ctrl: Drink } \\
\text { Test 2: Drink with 200mg } \\
\text { Ca } \\
\text { Ctrl: Drink } \\
\text { Test 1: Drink with 100mg } \\
\text { Ca } \\
\text { Ctrl: Drink }\end{array}$ & $\begin{array}{c}\text { Mean }(-\mathrm{SD},+\mathrm{SD}) \\
10.1(6.1,16.7) \\
7.8(4.9,12.5) \\
\\
10.2(5.6,18.7) \\
6.8(3.8,12.3)\end{array}$ & Moderate \\
\hline
\end{tabular}




\begin{tabular}{|c|c|c|c|c|c|c|c|c|c|}
\hline $\begin{array}{l}\text { Author } \\
\text { (year) }\end{array}$ & $\begin{array}{c}\text { City, } \\
\text { Country }\end{array}$ & $\begin{array}{l}\text { Design; } \\
\text { Sample } \\
\text { size }(N)\end{array}$ & $\begin{array}{c}\text { Age; } \\
\text { \%Female }\end{array}$ & $\begin{array}{c}\text { Baseline } \\
\text { hematologic } \\
\text { status }\end{array}$ & $\begin{array}{c}\text { Duration of } \\
\text { intervention }^{1}\end{array}$ & Outcomes & $\begin{array}{c}\text { Description of } \\
\text { intervention (categories) }\end{array}$ & Findings $^{2}$ & $\begin{array}{c}\text { Risk of } \\
\text { bias }\end{array}$ \\
\hline & & & & & & & $\begin{array}{l}\text { Test 2: Drink with 200mg } \\
\text { Ca }\end{array}$ & & \\
\hline \multirow[t]{2}{*}{ Yan (1996) } & $\begin{array}{l}\text { Keneba \& } \\
\text { Manduar, } \\
\text { The Gambia }\end{array}$ & $\begin{array}{c}\mathrm{RCT} \\
(\mathrm{N}=60\end{array}$ & $\begin{array}{l}28 y \\
100 \%\end{array}$ & $\begin{array}{l}\text { Mean ferritin: } \\
20.4 \mu \mathrm{g} / \mathrm{L}\end{array}$ & $\begin{array}{l}\text { Intervention: } 5 \mathrm{~d} \\
\text { weekly for } 52 \mathrm{wk} \\
\text { Follow-up: } 52 \mathrm{wk} \\
\quad \& 78 \mathrm{wk}\end{array}$ & Serum ferritin, $\mu \mathrm{g} / \mathrm{L}$ & $\begin{array}{c}\text { Test: Two calcium } \\
\text { supplements 500mg each } \\
\text { daily } \\
\text { Ctrl: Placebo }\end{array}$ & $\begin{array}{c}\text { Mean } \pm \text { SD at } 52 \mathrm{wk} \\
\text { Test: } 1.2 \pm 0.4 \\
\text { Ctrl: } 1.1 \pm 0.4\end{array}$ & Moderate \\
\hline & & & & & & & & $\begin{array}{c}\text { Mean } \pm \text { SD at } 78 \mathrm{wk} \\
\text { Test: } 1.2 \pm 0.4 \\
\text { Ctrl: } 1.1 \pm 0.3\end{array}$ & \\
\hline
\end{tabular}

${ }^{\mathrm{I}}$ Follow-up begins from the first day of the intervention to the day of evaluation.

${ }^{2}$ Findings are means \pm SD or mean (95\% confidence interval) or means (SE). NR - Not reported. NA - Not applicable.

${ }^{3}$ Abbreviations: Ca - calcium; Geom - Geometric; IDA - Iron Deficiency Anemia; $\quad$ sTfR - soluble transferrin receptor

${ }^{4}$ Only the highest and lowest outcome measures shown, but outcome measures not shown were considered for the dose-response analysis. 
medRxiv preprint doi: https://doi.org/10.1101/2020.09.21.20198358; this version posted September 23, 2020. The copyright holder for this preprint (which was not certified by peer review) is the author/funder, who has granted medRxiv a license to display the preprint in perpetuity. All rights reserved. No reuse allowed without permission. 


\section{Supplement 1. PRISMA Checklist}

\begin{tabular}{|c|c|c|c|}
\hline \multicolumn{3}{|l|}{ TITLE } & \\
\hline Title & 1 & Identify the report as a systematic review, meta-analysis, or both. & 1 \\
\hline \multicolumn{3}{|l|}{ ABSTRACT } & \\
\hline $\begin{array}{l}\text { Structured } \\
\text { summary }\end{array}$ & 2 & $\begin{array}{l}\text { Provide a structured summary including, as applicable: background; objectives; data sources; study } \\
\text { eligibility criteria, participants, and interventions; study appraisal and synthesis methods; results; } \\
\text { limitations; conclusions and implications of key findings; systematic review registration number. }\end{array}$ & $2-3$ \\
\hline \multicolumn{3}{|l|}{ INTRODUCTION } & \\
\hline Rationale & 3 & Describe the rationale for the review in the context of what is already known. & $5-6$ \\
\hline Objectives & 4 & $\begin{array}{l}\text { Provide an explicit statement of questions being addressed with reference to participants, interventions, } \\
\text { comparisons, outcomes, and study design (PICOS). }\end{array}$ & 6 \\
\hline \multicolumn{3}{|l|}{ METHODS } & \\
\hline $\begin{array}{l}\text { Protocol and } \\
\text { registration }\end{array}$ & 5 & $\begin{array}{l}\text { Indicate if a review protocol exists, if and where it can be accessed (e.g., Web address), and, if } \\
\text { available, provide registration information including registration number. }\end{array}$ & 7 \\
\hline Eligibility criteria & 6 & $\begin{array}{l}\text { Specify study characteristics (e.g., PICOS, length of follow-up) and report characteristics (e.g., years } \\
\text { considered, language, publication status) used as criteria for eligibility, giving rationale. }\end{array}$ & $8-9$ \\
\hline Information sources & 7 & $\begin{array}{l}\text { Describe all information sources (e.g., databases with dates of coverage, contact with study authors to } \\
\text { identify additional studies) in the search and date last searched. }\end{array}$ & 7 \\
\hline
\end{tabular}




\begin{tabular}{|c|c|c|c|}
\hline Search & 8 & $\begin{array}{l}\text { Present full electronic search strategy for at least one database, including any limits used, such that it } \\
\text { could be repeated. }\end{array}$ & 7 \\
\hline Study selection & 9 & $\begin{array}{l}\text { State the process for selecting studies (i.e., screening, eligibility, included in systematic review, and, if } \\
\text { applicable, included in the meta-analysis). }\end{array}$ & 10 \\
\hline $\begin{array}{l}\text { Data collection } \\
\text { process }\end{array}$ & 10 & $\begin{array}{l}\text { Describe method of data extraction from reports (e.g., piloted forms, independently, in duplicate) and } \\
\text { any processes for obtaining and confirming data from investigators. }\end{array}$ & 11 \\
\hline Data items & 11 & $\begin{array}{l}\text { List and define all variables for which data were sought (e.g., PICOS, funding sources) and any } \\
\text { assumptions and simplifications made. }\end{array}$ & $11-12$ \\
\hline $\begin{array}{l}\text { Risk of bias in } \\
\text { individual studies }\end{array}$ & 12 & $\begin{array}{l}\text { Describe methods used for assessing risk of bias of individual studies (including specification of } \\
\text { whether this was done at the study or outcome level), and how this information is to be used in any } \\
\text { data synthesis. }\end{array}$ & 14 \\
\hline Summary measures & 13 & State the principal summary measures (e.g., risk ratio, difference in means). & 12 \\
\hline Synthesis of results & 14 & $\begin{array}{l}\text { Describe the methods of handling data and combining results of studies, if done, including measures of } \\
\text { consistency (e.g., } \mathrm{I}^{2} \text { ) for each meta-analysis. }\end{array}$ & $13-14$ \\
\hline $\begin{array}{l}\text { Risk of bias across } \\
\text { studies }\end{array}$ & 15 & $\begin{array}{l}\text { Specify any assessment of risk of bias that may affect the cumulative evidence (e.g., publication bias, } \\
\text { selective reporting within studies). }\end{array}$ & 14 \\
\hline Additional analyses & 16 & $\begin{array}{l}\text { Describe methods of additional analyses (e.g., sensitivity or subgroup analyses, meta-regression), if } \\
\text { done, indicating which were pre-specified. }\end{array}$ & 14 \\
\hline \multicolumn{3}{|l|}{ RESULTS } & \\
\hline
\end{tabular}




\begin{tabular}{|c|c|c|c|}
\hline Study selection & 17 & $\begin{array}{l}\text { Give numbers of studies screened, assessed for eligibility, and included in the review, with reasons for } \\
\text { exclusions at each stage, ideally with a flow diagram. }\end{array}$ & $15,48, \mathrm{SI}$ \\
\hline $\begin{array}{l}\text { Study } \\
\text { characteristics }\end{array}$ & 18 & $\begin{array}{l}\text { For each study, present characteristics for which data were extracted (e.g., study size, PICOS, follow- } \\
\text { up period) and provide the citations. }\end{array}$ & $41-44$ \\
\hline $\begin{array}{l}\text { Risk of bias within } \\
\text { studies }\end{array}$ & 19 & Present data on risk of bias of each study and, if available, any outcome level assessment (see item 12). & $15-21$ \\
\hline $\begin{array}{l}\text { Results of } \\
\text { individual studies }\end{array}$ & 20 & $\begin{array}{l}\text { For all outcomes considered (benefits or harms), present, for each study: (a) simple summary data for } \\
\text { each intervention group (b) effect estimates and confidence intervals, ideally with a forest plot. }\end{array}$ & $\begin{array}{l}15-21, \text { SI, } \\
\text { Figures }\end{array}$ \\
\hline Synthesis of results & 21 & Present results of each meta-analysis done, including confidence intervals and measures of consistency. & $15-21$ \\
\hline $\begin{array}{l}\text { Risk of bias across } \\
\text { studies }\end{array}$ & 22 & Present results of any assessment of risk of bias across studies (see Item 15). & $15-21$ \\
\hline Additional analysis & 23 & $\begin{array}{l}\text { Give results of additional analyses, if done (e.g., sensitivity or subgroup analyses, meta-regression [see } \\
\text { Item 16]). }\end{array}$ & $15-21$ \\
\hline \multicolumn{4}{|l|}{ DISCUSSION } \\
\hline $\begin{array}{l}\text { Summary of } \\
\text { evidence }\end{array}$ & 24 & $\begin{array}{l}\text { Summarize the main findings including the strength of evidence for each main outcome; consider their } \\
\text { relevance to key groups (e.g., healthcare providers, users, and policy makers). }\end{array}$ & $22-23$ \\
\hline Limitations & 25 & $\begin{array}{l}\text { Discuss limitations at study and outcome level (e.g., risk of bias), and at review-level (e.g., incomplete } \\
\text { retrieval of identified research, reporting bias). }\end{array}$ & 24 \\
\hline Conclusions & 26 & $\begin{array}{l}\text { Provide a general interpretation of the results in the context of other evidence, and implications for } \\
\text { future research. }\end{array}$ & $27-28$ \\
\hline \multicolumn{3}{|l|}{ FUNDING } & \\
\hline
\end{tabular}


medRxiv preprint doi: https://doi.org/10.1101/2020.09.21.20198358; this version posted September 23, 2020. The copyright holder for this preprint (which was not certified by peer review) is the author/funder, who has granted medRxiv a license to display the preprint in perpetuity.

All rights reserved. No reuse allowed without permission.

Supplement 2. Search Strategy

\begin{tabular}{|c|c|c|c|}
\hline Database & Search query & Original search & Updated search \\
\hline PUBMED & $\begin{array}{l}\text { ("Iron"[Mesh] AND } \quad \text { "Calcium"[Mesh]) } \\
\text { AND } \\
\text { absorption"[MeSH Terms] OR "biological } \\
\text { availability"[Mesh] OR "inhibition"[All } \\
\text { Fields] OR "interaction"[All Fields] OR } \\
\text { "Iron-Binding Proteins"[Mesh] OR "Iron- } \\
\text { Regulatory Proteins"[Mesh] OR } \\
\text { "Hematologic Diseases"[Mesh]) }\end{array}$ & 505 & 47 \\
\hline EMBASE & $\begin{array}{l}\text { 'iron'/exp AND 'calcium'/exp AND } \\
\text { ('bioavailability'/exp OR 'gastrointestinal } \\
\text { absorption'/exp OR 'iron regulatory } \\
\text { factor'/exp OR 'iron binding protein'/exp } \\
\text { OR 'anemia'/exp) AND [embase]/lim } \\
\text { NOT [medline]/lim NOT 'review'/it }\end{array}$ & 549 & 164 \\
\hline
\end{tabular}

\section{Supplement 3. Risk of Bias Assessment of randomized controlled trials}

\begin{tabular}{|c|c|c|c|c|c|}
\hline $\begin{array}{c}\text { Author (year of } \\
\text { publication) }\end{array}$ & $\begin{array}{c}\text { Random sequence } \\
\text { generation }\end{array}$ & $\begin{array}{c}\text { Blinding of participants and } \\
\text { personnel }\end{array}$ & $\begin{array}{c}\text { Incomplete outcome } \\
\text { data }\end{array}$ & $\begin{array}{c}\text { Measurement of } \\
\text { outcome }\end{array}$ & $\begin{array}{l}\text { Selective } \\
\text { reporting }\end{array}$ \\
\hline Agustina (2013) & Low & High & High & Low & Low \\
\hline $\begin{array}{l}\text { Faghih (2012) } \\
\text { Grinder-Pederson }\end{array}$ & Low & High & High & Low & Low \\
\hline $\begin{array}{l}\text { Hallberg (1993) } \\
\text { Israel Rios-Castillo } \\
\text { (2014) }\end{array}$ & $\begin{array}{l}\text { Low } \\
\text { Low }\end{array}$ & High & High & Low & Low \\
\hline Minihane (1998) & Low & High & Low & Low & Low \\
\hline Miranda (2014) & Low & High & Low & Low & Low \\
\hline Reddy (2000) & Some concerns & High & Low & Low & Low \\
\hline
\end{tabular}


medRxiv preprint doi: https://doi.org/10.1101/2020.09.21.20198358; this version posted September 23, 2020. The copyright holder for this preprint (which was not certified by peer review) is the author/funder, who has granted medRxiv a license to display the preprint in perpetuity.

All rights reserved. No reuse allowed without permission.

\begin{tabular}{|c|c|c|c|c|c|}
\hline Sokoll (1992) & Low & Low & Low & Low & Low \\
\hline Walczyk (2014) & Low & High & Low & Low & Low \\
\hline Yan (1996) & Low & High & Low & Low & Low \\
\hline
\end{tabular}

Supplement 4. Risk of Bias Assessment for Crossover trials

\begin{tabular}{|c|c|c|c|c|c|c|}
\hline $\begin{array}{c}\text { Author (year of } \\
\text { publication) }\end{array}$ & $\begin{array}{c}\text { Random sequence } \\
\text { generation }\end{array}$ & $\begin{array}{c}\text { Blinding of } \\
\text { participants and } \\
\text { personnel }\end{array}$ & $\begin{array}{c}\text { Incomplete } \\
\text { outcome data }\end{array}$ & $\begin{array}{c}\text { Measurement of } \\
\text { outcome }\end{array}$ & $\begin{array}{l}\text { Selective } \\
\text { reporting }\end{array}$ & $\begin{array}{c}\text { Carryover } \\
\text { effects }\end{array}$ \\
\hline Abrams (2001) & Low & Low & Low & Low & Low & High \\
\hline Benkedda (2010) & Low & Some concerns & Low & Low & Low & Low \\
\hline $\begin{array}{l}\text { Cook (1991) } \\
\text { Dawson-Hughes }\end{array}$ & Low & Some concerns & Low & Low & Low & Low \\
\hline Deehr (1990) & Low & Some concerns & Low & Low & Low & Low \\
\hline Gaitan (2011) & Some concerns & High & Low & Low & Low & Some concerns \\
\hline Galan (1991) & Low & High & Low & Low & Low & Low \\
\hline Gleerup (1993) & Some concerns & High & Low & Low & Low & Some concerns \\
\hline Reddy (1997) & Low & High & Low & Low & Low & Low \\
\hline Roughead (2002) & Low & High & Low & Low & Low & Low \\
\hline Roughead (2005) & Low & High & Low & Low & Low & Low \\
\hline Walczyk (2014) & Low & High & Low & Low & Low & Low \\
\hline
\end{tabular}

${ }^{1}$ For crossover studies, studies with "Some concerns" random sequence generation where those that did not specify whether the order of treatments was randomized or not. 
medRxiv preprint doi: https://doi.org/10.1101/2020.09.21.20198358; this version posted September 23, 2020. The copyright holder for this preprint (which was not certified by peer review) is the author/funder, who has granted medRxiv a license to display the preprint in perpetuity.

\section{PRISMA 2009 Diagram}

\section{Records identified through} database searching

$(n=1,265)$

Records after duplicates removed

$(n=1,209)$

Additional records identified through other sources

$$
(n=22)
$$

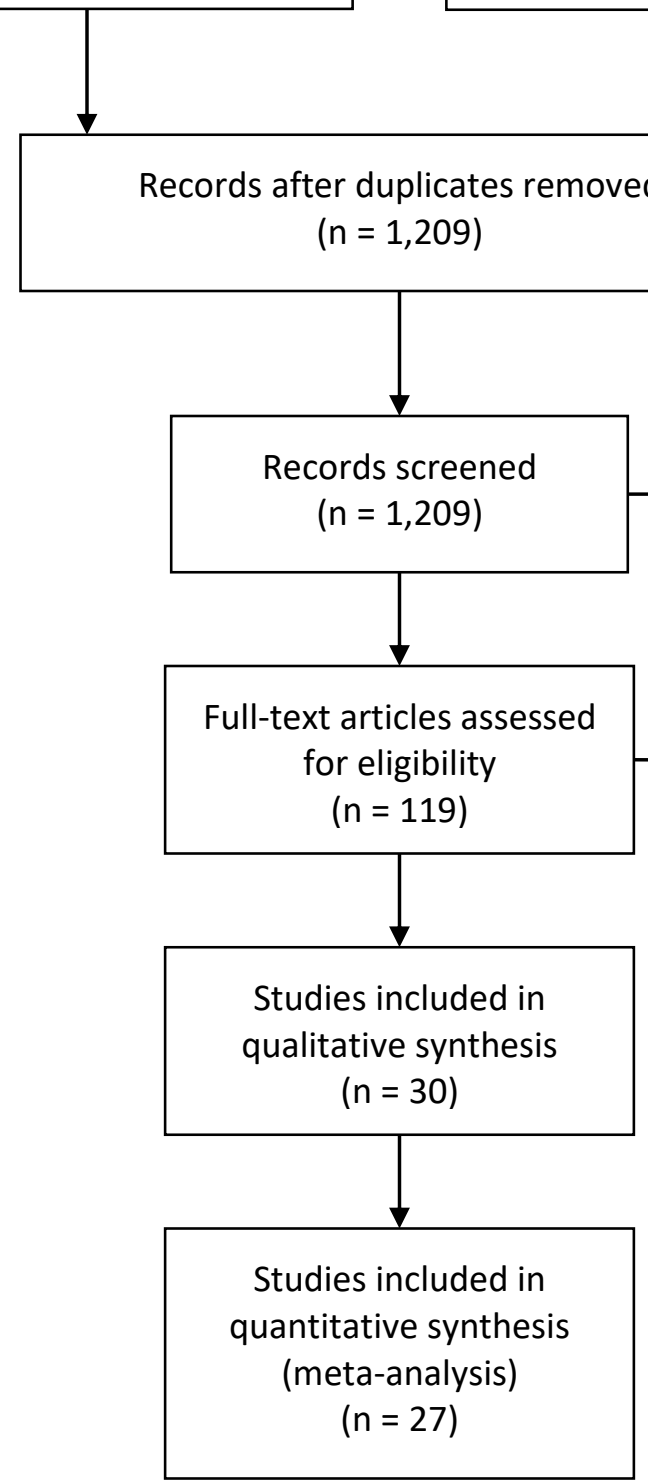

From: Moher D, Liberati A, Tetzlaff J, Altman DG, The PRISMA Group (2009). Preferred Reporting Items for Systematic Reviews and MetaAnalyses: The PRISMA Statement. PLoS Med 6(7): e1000097. doi:10.1371/journal.pmed1000097 


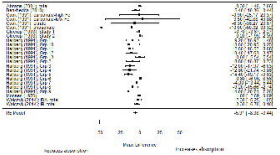




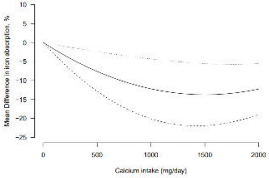


Halber i yes, rarbuger IIdbug it as? wiadica liagiens icasth Eop $\mathrm{A}$

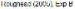
tititu Certan $20<1$. L II:Alue (19:1)

Ist hode

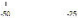

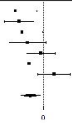

Nesn uitersics

$$
\begin{aligned}
& \text { 1:.6V| } 1324,2.411 \\
& -510[-7471,-240] \\
& \text { s.0। } 1041,0.19 \\
& \text { vi.20 } 180 \%, 1.21 \\
& \text { - o. [4. 4 4] } \\
& \therefore .0|10 \div 0,0.11| \\
& 420 \mid-2: 2,10 \div 2] \\
& 1 \times 4 \mid 65 y, 1.24
\end{aligned}
$$$$
1
$$$$
\text { re }
$$$$
\text { si) }
$$ 
Hareeg 19\%

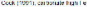

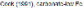

Gin iागयi:

rimicy tooty

ritis te 17:4s:

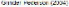

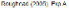

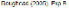

Gatar Gevil:

Gatal $6 \mathrm{NJI}$ إ

rintey rosicy

rifurd
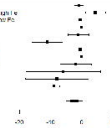

1.CU1 $2.22 \quad 3>2 \mid$ ay $1.12+31$

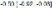
\& \$1. [-8 $11,7 \div]$

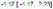
$11.121465,9.121$ C. $=\mathrm{El} 2.22$ 1 22। s. if. $[-2.25$ \% \& 6. [-7.2 3.7] Lx। $12.22>+21$ 4.6i 1s.11. 2.1 iा

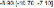

3 If $\left[\begin{array}{lll}-128 & 110\end{array}\right]$

10

71

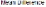




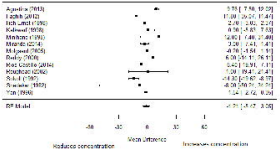




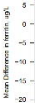

$-25$
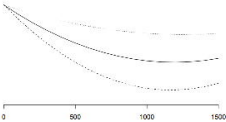

Cacumitgke (ropitsy) 
katrasti i

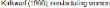

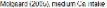

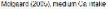

Aysolia (7.13)

Bixnse P211।

Ris-Cosila!201d:

Id Erentiven

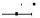

a

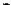
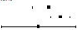

1 उखy|

-7 ก. $[-4.2 ! 330$

1.09| 0.18 .1 .321

20j $228,2.121$

$\because \mathrm{AC}[-5 \mathrm{x}, 2 \cdot$ ค]

$\langle\omega\rangle|\langle z\rangle, 3.20|$

$220 \div 1248,2$ 的] $200|3 \%, 0.23|$

n4 [-59: 170

ก

$\rightarrow \mathbb{F}$

Pean Diterance 